\title{
PRINCIPIOS PARA UN ADECUADO ESTATUTO DEL CONSUMIDOR. LA CONSTRUCCION DE ESE ESTATUTO EN EUROPA ${ }^{1}$
}

\author{
Ricardo de Angel Yágüez \\ Catedrático de Derecho civil de la Universidad de Deusto (Bilbao, España)
}

Sumario: I. Introducción: propósito, contenido y estructura de la presente aportación. II. La posición del consumidor y el ejercicio de sus derechos. 1. Las circunstancias que caracterizan la figura del consumidor. Su tradicional «resignación» y el fenómeno actual conocido como «la fiebre de las demandas». El difícil equilibrio entre la salvaguarda del consumidor y la racionalidad jurídica y económica. 2. El ejercicio de los derechos por parte del consumidor. Limitaciones que pesan sobre la reclamación judicial. Una experiencia norteamericana: las «class actions». III. Algunos de los principales problemas técnico-jurídicos que plantea la protección del consumidor. IV. Las formas en que se ha articulado en Europa el «sistema» jurídico de protección del consumidor. V. La Ley (española) general para la defensa de los consumidores y usuarios, de 19 de julio de 1984. 1. Campo de aplicación de la Ley. 2. Régimen de responsabilidad por productos o servicios. 3. Las vías de indemnización. 4. Responsabilidad solidaria. 5. El seguro obligatorio. VI. La Directiva europea sobre responsabilidad por los daños causados por productos defectuosos y la Ley española sobre la misma materia. 1. La Directiva de las Comunidades Europeas. 2. La Ley española de responsabilidad civil por los daños causados por productos defectuosos. VII. El proyecto de Ley español sobre condiciones generales de la contratación. Régimen (añadido) de las cláusulas abusivas en los contratos celebrados con consumidores. 1. Introducción: justificación del proyecto y aspectos de técnica legislativa. 2. Consideraciones previas sobre el contenido de la Ley proyectada. 3. Régimen de las condiciones generales de la contratación. 3.1. Rasgos generales. 3.2. Concepto de condiciones generales de la contratación. 3.3. Ambito territorial de la Ley. 3.4. Contratos excluidos. 3.5. Requisitos de incorporación y cláusulas

1 El texto que se reproduce a continuación es la versión reducida de la ponencia preparada por el autor para su exposición en el III Encuentro Internacional de responsabilidad y seguros, a celebrar en Medellín (Colombia) los días 12 y 13 de noviembre de 1997. 
no incorporadas. 3.6. Reglas de interpretación. 3.7. Nulidad de las condiciones generales. La propia de las abusivas. 4. El Registro de Condiciones Generales de la Contratación. 5. Acciones colectivas de cesación, retractación y declarativa de condiciones generales. 6. La disposición adicional primera de la Ley. 6.1. La nueva redacción del artículo 10 de la LCU. 6.2. Introducción de un nuevo artículo 10 bis y de una disposición adicional primera en la LCU (régimen específico de las cláusulas abusivas).

\section{Introducción: propósito, contenido y estructura de la presente aportación}

1. Me tomo la libertad de refundir en una única exposición los dos temas que me han sido propuestos en este Encuentro.

Lo hago así porque creo que el régimen general de protección legal del consumidor alcanzado hoy en Europa (por tanto, no me refiero sólo a productos) constituye un «sistema» (en el sentido científico de esta palabra) que podría considerarse modélico o ejemplar para cualquier ordenamiento jurídico. Me refiero, desde luego, al de un país con un nivel medio de rentas (en definitiva, un nivel medio de vida) que pueda calificarse de elevado o avanzado. Es decir, podría entenderse que ese régimen europeo contiene un conjunto de «bases» ajustadas a una «adecuada» protección del consumidor, tal y como reza la segunda ponencia que se me ha atribuido.

De este modo, como decía, no parece inoportuno que me haya inclinado a reunir en un único trabajo las dos ponencias que se me han asignado en este Encuentro, porque entiendo que existe entre ellas una evidente vinculación.

Pero debo explicar por qué me refería antes a países en que el nivel de vida puede calificarse de alto, en el sentido que convencionalmente atribuimos a este adjetivo.

Lo he puntualizado porque considero que es un error creer que los instrumentos jurídicos —en general, en cualquier materia - son «trasplantables» de un país a otro. Estimo, por el contrario, que deben tenerse siempre presentes los presupuestos económicos o de desarrollo de cada sociedad. Cuando una masa considerable de la población tiene por aspiración la de «consumir» (sean productos o servicios) de los que 1lamamos «de primera necesidad», puede resultar irónico o incluso hipócrita hablar de «tutela del consumidor». Habría sido, por ejemplo, el caso de la Europa de la postguerra, y en concreto el de la España de su postguerra civil. No es casualidad, ciertamente, que la inquietud doctri- 
nal en materia de consumo se manifestara en los años setenta (estando ya Europa en situación de razonable bienestar medio), y en España incluso más tarde.

Considero que hay que tener presentes incluso datos de orden sociológico, como es el que en algún lugar he llamado «conciencia de consumidor»; es decir, una generalizada convicción del ciudadano de que se encuentra en situación de injusta inferioridad respecto a las grandes empresas (o cadenas de empresas) fabricantes de productos o dispensadoras de servicios de amplia utilización.

Por eso, me parece que es justificado el consejo de actuar, en esta materia, con prudencia y con una buena dosis de realismo. Por ejemplo, estimo que una brusca y radical introducción de criterios de responsabilidad objetiva (por citar uno de los instrumentos jurídicos más característicos en este terreno) podría causar efectos contraproducentes desde el punto de vista de la promoción del desarrollo técnico y económico y en el plano de lo que podríamos considerar una «razonable litigiosidad» $»^{2}$.

2. Debo advertir también que, en general, tomo como referencia para este trabajo el Derecho español.

Lo hago por un motivo fácil de explicar. Es porque nuestro ordenamiento jurídico ha dado (o está terminando de dar) los pasos necesarios para acomodarse al «modelo europeo». En primer lugar, porque su legislación que llamaríamos «privativa» ha sentado los principios de una protección del consumidor merecedora de la consideración de adecuada, proporcionada o, dicho de otro modo, «justa» ${ }^{3}$. En segundo término, porque la pertenencia de España, desde 1986, a la hoy denominada Unión Europea nos ha introducido de lleno en el marco del llamado «Derecho comunitario». Esto se traduce en la eficacia directa de los abundantísimos Reglamentos de la Unión en materia de consumo y en la necesidad de adaptar nuestro ordenamiento a las importantes Directivas - siempre dentro de nuestro objeto- que manan de los órganos de la Comunidad. Más adelante tendremos oportunidad de comprobarlo y documentarlo. Pero lo que quiero decir es, en suma, que hoy España representa, también en la cuestión que nos ocupa, un ejemplo de lo que cabalmente podemos considerar «el Derecho europeo». Más aún, en

2 Uso estas últimas palabras como expresión de un grado o nivel, también aceptable o tolerable, de «conflictividad» entre empresas y ciudadanos consumidores.

3 En la medida en que pueda utilizarse esta expresión («justa») en un ámbito, como es el consumo, que cada día plantea nuevos problemas y suscita nuevas demandas por parte de una sociedad abocada a ser más consumidora; y de serlo, por otro lado, de bienes y servicios cada vez más sofisticados y de alguna manera más peligrosos. 
ciertos aspectos el Derecho español ha ido más lejos que las normas comunitarias: es un ejemplo el caso de nuestra Ley general para la defensa de consumidores y usuarios, de 1984, que hace llegar su protección no sólo a los daños causados por productos defectuosos, sino también a los derivados de servicios defectuosos.

3. Me refiero ahora al contenido del trabajo que aporto en este Encuentro.

En primer lugar, formulo unas consideraciones previas, o de análisis general, sobre el fenómeno que está en la raíz de la materia que nos ocupa. Es decir, en torno a la aparición y desarrollo entre los juristas de un clima de inquietud por dotar al consumidor de armas jurídicas bastantes para ponerle a cubierto de la situación de inferioridad en que normalmente se encuentra frente a las empresas de producción y de servicios.

A continuación, me ocupo de la descripción de los problemas fundamentales que, desde el punto de vista técnico-jurídico, ha sido necesario afrontar y resolver para la articulación de un sistema eficaz y realista de tutela del consumidor.

A renglón seguido, hago una sucinta exposición de la forma en que se ha construido un conjunto normativo apto para ser calificado como «Derecho del consumo» ${ }^{4}$.

Luego dedico cierto detalle a las leyes más significativas en nuestro ámbito, con lo que quiere ser un proporcionado comentario de su contenido respectivo.

Por fin, incluyo en este trabajo una serie de apéndices en que se reproducen algunos de esos textos legales que estimo fundamentales en la materia. En alguna ocasión aporto lo que todavía son meros proyectos, algunos en curso de materialización o próxima traducción en leyes efectivas, e incluso otros hoy «estacionados» o suspendidos porque no se han resuelto todavía los considerables problemas de orden políticoeconómico que las correspondientes iniciativas legislativas han planteado. Ejemplo de lo primero es el Proyecto de Ley español sobre condiciones generales de la contratación, que, a pesar de su nombre, no se va a limitar a lo que esa denominación sugiere, sino que va a llevar a cabo la transposición o incorporación al Derecho español de la Directiva del

\footnotetext{
4 «Derecho del consumo» que, a mi juicio, no es una disciplina jurídica autónoma, sino sólo un modo de hablar y de entendernos que únicamente representa una construcción útil desde el punto de vista de la política legislativa o desde una perspectiva académica. Sin perjuicio de que pueda constituir una especialización profesional, sobre todo dentro de la estructura de la Administración pública.
} 
Consejo de la Unión Europea sobre cláusulas abusivas en los contratos celebrados con consumidores. Y ejemplo de lo segundo es la propuesta de Directiva comunitaria sobre la responsabilidad del prestador de servicios: esa propuesta se halla hoy retirada, siquiera provisionalmente, por las considerables reservas que ha suscitado (se supone que no sin intervención de ciertos grupos de presión particularmente poderosos) la generalizada introducción - que la propuesta pretendía- de un principio de presunción de culpa del prestador de servicios y consecuente inversión de la carga de la prueba, carga que pasaría a este último.

\section{La posición del consumidor y el ejercicio de sus derechos}

Dedico este capítulo a formular algunas consideraciones de carácter general sobre circunstancias que subyacen al fenómeno del consumo; sobre el todavía no muy lejano alumbramiento de las inquietudes de los juristas por la figura del consumidor (en definitiva, las inquietudes de este último) y en torno a lo que mi juicio constituye el problema todavía sin resolver debidamente, esto es, el del ejercicio por el consumidor de los derechos que las normas legales establecen en su favor ${ }^{5}$.

1. Las circunstancias que caracterizan la figura del consumidor. Su tradicional «resignación» y el fenómeno actual conocido como «la fiebre de las demandas». El difícil equilibrio entre la salvaguarda del consumidor y la racionalidad jurídica y económica.

Es frecuente hablar de los «derechos del consumidor». Sin embargo, aunque todos entendamos la expresión, creo que contemplar al consumidor desde la perspectiva de sus derechos no es del todo correcto. Se crea la impresión de que aquél ostenta unas prerrogativas especiales, como si se tratara de un titular de derechos de carácter privilegiado.

Estimo que ese punto de vista desorbita un tanto las cosas, pues bajo el prisma jurídico el consumidor no es sino una de las partes de un contrato, como cualquier otro. Lo que en cambio sí atribuye al consumidor una evidente peculiaridad es su posición, esto es, la situación en

5 Reproduzco en parte, y con algunas actualizaciones, lo que sobre este punto escribí en DE ANGEL YÁGÜEZ, La posición del consumidor y el ejercicio de sus derechos. Daños causados por productos defectuosos, en «Estudios sobre el Derecho de consumo», 2. ${ }^{\text {a }}$ edición, Bilbao, 1994, páginas 58-105. 
que se encuentra en todas y cada una de las relaciones contractuales que permiten dar esa denominación (la de consumidor) a un determinado sujeto. Y esa posición, según creo, no deriva tanto de presupuestos jurídicos, sino de consideraciones de orden sociológico. Dicho de otro modo, la variada reglamentación jurídica de lo que concierne al fenómeno del consumo no es, quizá, un prius teórico, sino simple producto de la aplicación de las reglas de Derecho sobre unas determinadas hipótesis que la realidad económica suministra.

Vistas las cosas desde el ángulo de la contratación, lo que otorga una cierta personalidad o identidad a la figura del consumidor consiste, entre otras cosas, en lo siguiente:

En primer lugar, el consumidor merece este apelativo en cuanto es parte en numerosos contratos, que a veces celebra varias veces al día (desde luego, sin tener conciencia del significado jurídico de lo que hace), sobre todo para subvenir o atender intereses vitales que socialmente se juzgan inexcusables (o casi inexcusables) y que por ello merecen la consideración de «necesidades».

Por ello mismo, en segundo término, cuando pensamos en los contratos que concierta el consumidor se nos vienen abajo muchos de los cánones técnico-jurídicos clásicos; sobre todo, la idea de que el contrato es una expresión de la libertad humana y de que, por ello, no sólo se parte de la base de que todo el mundo es libre de contratar o no contratar, sino de la de que cuando uno contrata lo hace en términos de rigurosa igualdad respecto a la otra parte, de suerte que el acuerdo de voluntades es fruto de una negociación o discusión más o menos intensa.

Sin necesidad de acudir a formulaciones doctrinales que evidencian lo mucho que en la sociedad actual el contrato difiere de lo que filosóficamente entendemos como tal, basta reparar en la circunstancia de que hoy en día el ciudadano se ve sometido a una auténtica obligación de contratar.

Podría pensarse en teoría en la posibilidad de que una persona se resistiera a gozar de bienes de consumo: un individuo que escapa a la compra de ciertos productos alimenticios o a la asistencia sanitaria (o para no exagerar, a la adquisición de objetos de limpieza, aseo o diversión), o que se sustrae a la utilización de servicios como el agua o la luz de casa, o que resiste con fiereza a la tentación de los electrodomésticos, los automóviles o los juguetes para sus hijos. Pero la vida se encarga de demostrar que eso es pura hipótesis. En todos estos casos podría pensarse que subsiste lo que en expresión muy afortunada llamó un autor francés «la opción fundamental de contratar o no contratar», entendiendo por tal la libertad de que en abstracto goza la persona para decidir si se somete o no a las condiciones que la otra parte (el vende- 
dor de alimentos, el promotor al que se compra la vivienda, el suministrador de energía eléctrica, la empresa de transportes) le impondría si quisiera disfrutar los bienes que estos últimos están en condiciones de proporcionarle. Pero esto es también pura imaginación. Salvo que uno quiera resignarse a una vida de carencias (no pocas veces mal vista por la propia sociedad), la celebración de los contratos que nos convierten en consumidores ha pasado a ser un verdadero imperativo, de forma que incluso aquella «opción fundamental» ha quedado en el terreno de la especulación. Podría decirse, en una palabra, que respecto a una gran multitud de bienes o servicios ya no tiene el individuo ni siquiera libertad de contratar.

Otra circunstancia íntimamente vinculada a las que acabamos de exponer es la de que la figura del consumidor, desde el punto de vista jurídico, es la de quien por medio de un contrato accede a bienes o servicios que para él tienen un marcado carácter personal, pero que son dispensados en masa, esto es, en grandes cantidades, por empresas de cada día mayor volumen (como consecuencia del fenómeno de la concentración jurídica o de la simplemente económica); para las cuales, cada concreto consumidor no es sino un despersonalizado protagonista de operaciones económicas, no pocas veces identificado por un número clave o una simple referencia de ordenador.

Se une a todo lo anterior el hecho de que en la mayor parte de los casos los contratos en que el comprador se ve inmerso (bien puede utilizarse esta expresión) son de no muy grande importancia económica, o que aun teniéndola no se siente como tal (a causa de plazos, abonos, suscripciones, facturaciones muy frecuentes, etc.); lo que se traduce en una habitual displicencia del consumidor, no pocas veces desinterés, respecto de lo que la otra parte del contrato haga, no haga o disponga. Pensamos que el billete de tren, o la liquidación bancaria de intereses, o la póliza de nuestro seguro de riesgos del hogar, son cosas de arte menor, pequeñeces que no deben distraer nuestra agitada vida.

Es ya tópico aludir al escaso interés que prestamos a las llamadas condiciones generales, esto es, a las cláusulas que la empresa oferente de bienes o servicios suele incluir en sus contratos (a menudo ya impresos, con escasos espacios en blanco para identificar al cliente y poco más, y por si fuera poco «en letra pequeña», como también es usual poner de manifiesto), cláusulas en que casi todo se prevé desde el punto de vista al menos, de la propia empresa; y con frecuencia, en su exclusivo interés. Ni que decir tiene que me refiero a los llamados contratos de adhesión, así denominados porque lo que el consumidor hace es, simplemente, aceptar o someterse a las condiciones contractuales que la otra parte tiene establecidas con carácter de estipulaciones-tipo o 
standard (de «contratos standard» suele hablar en estos casos, por eso, la doctrina jurídica).

De ahí que el consumidor sea un contratante de actitudes normalmente tolerantes: no es mucho lo que está en juego, incluso cuando en el proceder de la otra parte no hay un correcto modo de actuar, porque en definitiva se trata de soportar una pequeña o pasajera contrariedad (el frigorífico que se avería más de lo razonable, la conserva cuyo mal estado advertimos antes de tomarla o el juguete que a los cuatro días está destrozado).

Esto hace del consumidor un contratante no demasiado cuidadoso para con sus intereses (sus derechos). Extremo que reviste una gran importancia en lo que se refiere al control judicial de los comportamientos contractuales incorrectos de la otra parte contratante, esto es, el suministrador o vendedor o quien presta los servicios.

En efecto, una máxima del Derecho romano dijo sabiamente: Vigilantibus, non dormientibus iura subveniunt; expresado en términos de hoy, corresponde a cada uno de nosotros hacer valer nuestros derechos y renunciar a ellos; salvo que el interés público esté en juego, ninguna autoridad, ningún tercero puede suplir a quien por su voluntad, por ignorancia o por descuido, deja de ejercitar sus derechos.

Ante lo que nos encontramos, pues, es ante multitud de intereses individuales, no demasiado significativos para cada uno de sus titulares, de entre los cuales son unos pocos, de ordinario, los que los hacen valer hasta sus últimas consecuencias mediante denuncias, reclamaciones o pleitos. Y eso, no pocas veces, sólo se hace por motivos de «dignidad», represalia o simple notoriedad. La mayoría, como decíamos, deja pasar. Ni siquiera cabe decir que transige o se resigna, porque la escasa importancia económica de lo que está en juego no le anima a discutir. Y ocurre muchas veces que, aun existiendo algún móvil para hacerlo, no se discute simplemente por razones económicas (no vaya a ser más cara la salsa que la perdiz, que reza el dicho popular) o para evitarse incomodidades no justificadas.

No sólo eso, sino que la misma tradición judicial no parece estar pensada para la reclamación por pequeñas cantidades o insignificantes intereses. De minimis non curat praetor: los jueces no están para pequeñeces. Es por ello motivo de periódico (noticia) el que se demande por el importe de una lata de conserva, o por el cobro de gastos de correo por parte de un banco, o a causa del cálculo incorrecto de una prima de seguro, o por un recibo de la luz.

En este punto, forzoso es reconocer que las cosas están cambiando un poco, aunque creo que no por causa de un extendido entusiasmo entre los consumidores, que somos todos. En parte está siendo por inicia- 
tiva de las asociaciones de consumidores y usuarios, cuya actuación ejemplar o testimonial no puede ponerse en entredicho pero quizá no siempre alentadas en su modo de proceder por grupos de población estadísticamente significativos.

Todo esto que acabo de decir ocurre y se vive en notable contraste con lo que a los intereses de empresas suministradoras se refiere. Lo que para cada consumidor o usuario es una bagatela, multiplicado por miles o cientos de miles puede constituir un capítulo decisivo de la cuenta de resultados de la empresa que vende o sirve. Y no sólo eso, sino que la circunstancia misma de que los consumidores no muestren una sensible propensión a reclamar o protestar constituye a su vez uno de los ingredientes (probablemente el más importante en la mayor parte de los casos) que explican esa falta de esmero, atención o rigor que con frecuencia se observa en el proceder de ciertas empresas con las que casi a diario contratamos.

A causa de la concurrencia de todas estas circunstancias, todavía son muy pocas entre nosotros las que podríamos denominar «reclamaciones de consumo». Sólo cuando ha ocurrido un daño considerable (una intoxicación extendida, un fraude notorio, una flagrante mala práctica empresarial) es cuando suele despertar la conciencia dormida del consumidor, tan dormida que no creo exagerado decir que cada uno de nosotros la ve mejor en los demás que en sí mismo; no es infrecuente que nos exaspere un agravio que a otro se le causa en materia de consumo, cuando acaso idéntico acontecimiento pueda pasarnos desapercibido siendo nosotros mismos sus víctimas.

El cuadro que estamos pintando, aunque quizá con pocas y torpes pinceladas, se complica todavía más cuando se trata de aquellos sectores del consumo en que, bien la propia naturaleza de los bienes o servicios, bien los avances tecnológicos, introducen o aumentan el riesgo de daños a los consumidores, que en ocasiones son muy grandes y alcanzan a sectores muy amplios de población. De todos son conocidos algunos trágicos episodios derivados del consumo de alimentos, de la manipulación de electrodomésticos aparentemente inofensivos, de la toma de medicamentos o de la aplicación de insecticidas o cosméticos. En presencia de casos como éstos, y contemplando la cuestión con el debido desapasionamiento, no puede ignorarse la concurrencia de intereses contrapuestos. De un lado, la necesidad de dotar de suficiente protección a los consumidores, persiguiendo la máxima pulcritud en la fabricación de los bienes y en la prestación de los servicios, pero por otra parte la necesidad también de no sofocar el progreso industrial y la implantación de nuevas tecnologías o la introducción de productos nuevos. Se trata, a mi juicio, de un ejemplo patente de obligada búsqueda 
del equilibrio (nada fácil) entre los intereses de cada individuo aisladamente considerado (la potencial víctima de un daño), y los de la colectividad como conjunto. Con interferencia además, muchas veces, de factores de orden macroeconómico que los poderes públicos e incluso los jueces no pueden olvidar.

He querido poner de relieve que nos hallamos sobre un terreno movedizo y frágil. De lo que se trata es de alcanzar el difícil equilibrio entre la salvaguarda de los intereses del consumidor, de suerte que éstos queden a cubierto de todo abuso, y el objetivo de que la empresa soporte sus deslices (de mayor o menor calibre) en la fabricación del producto o prestación del servicio, pero sin caer en exageraciones que dañarían el conjunto del sistema económico, con perjuicio a su vez para los propios ciudadanos. Una expresión concreta de este posible «daño indirecto»o «por carambola» es el consistente en el encarecimiento de bienes o servicios, provocado por las altas primas que el fabricante o suministrador tiene que satisfacer si quiere ponerse a salvo (a través de un adecuado y suficiente seguro de responsabilidad civil) del riesgo de reclamaciones judiciales constitutivas de un verdadero peligro para la supervivencia de la empresa.

Precisamente porque en esta materia pueden estar en juego intereses económicos colectivos (que a veces se postergan u olvidan cuando estamos en presencia de una concreta reclamación) es por lo que en los últimos tiempos se viene prestando tanta atención al coste de los accidentes, con planteamientos y propuestas que acaso no sean de recibo si nos atenemos a un frío análisis económico del Derecho (sobre el que tanto se ha escrito, sobre todo en Estados Unidos), pero que obligan a replantear las cosas en el aspecto jurídico para no incurrir en despropósitos.

Con independencia de que la responsabilidad de las empresas respecto al consumidor deba contemplarse con una visión realista de las cosas, valorando con rigor y sin pasión las circunstancias del producto o del servicio y el grado de formación del consumidor medio (para evitar resultados tan originales como el del automóvil que alcanza gran velocidad o el del paracaídas, de algunos curiosos precedentes norteamericanos), es necesario - a mi juicio - tener presente el deber de razonable diligencia que al consumidor debe aplicarse cuando adquiere o utiliza un producto o un servicio. Quizá no deba llegarse a fórmulas como las que alguna opinión jurídica ha propuesto (por ejemplo, la de que pague o soporte el daño quien tiene más culpa, aunque la otra parte tenga también alguna), porque parece que la figura de la compensación de culpas tiene muy razonable aplicación en este caso a efectos de reducir la cuantía de la indemnización procedente si la culpa única hubiese sido de la empresa. No creo que sea un despropósito decir que en so- 
ciedades en que el interés del consumidor está sobre todas las cosas se crea inevitablemente una relajación del cuidado por parte de los clientes, esto es, una actitud de escasa atención sobre las cosas que utilizan, pues en el fondo del ser humano está el descuido cuando ha de ser otro quien pague las consecuencias.

No menos digna de tenerse en cuenta es la circunstancia de que, al menos en ciertas sociedades, muchos de los riesgos que derivan del consumo se encuentran de alguna manera «pulverizados» (expresión gráfica de "socializados») a través del sistema de la seguridad social, que por vía del impuesto o figuras similares ha trasladado al conjunto de los individuos los daños derivados del uso o disfrute de bienes, los de hoy, que por experiencia sabemos que son cada vez más aptos para colocarnos en situación de peligro.

2. El ejercicio de los derechos por parte del consumidor. Limitaciones que pesan sobre la reclamación judicial. Una experiencia norteamericana: las «class actions».

En la actualidad, lo decíamos antes, la actitud del consumidor español es más beligerante que lo que fue en el pasado. Me estoy refiriendo al innegable fenómeno del crecimiento del número de reclamaciones judiciales en materia de consumo, que sin embargo no alcanza las cotas de algunos países extranjeros.

Pero si ahora aludo a este extremo (el ejercicio de sus derechos por parte de los consumidores) es para hacer alguna referencia a aspectos de orden práctico que es preciso atender en este materia, y a la forma en que se han resuelto en algunos países.

El punto de partida es la observación de que el «talón de Aquiles» de los derechos del consumidor está en su ejercicio, no en su definición o determinación. He advertido antes que la circunstancia de que el interés de cada concreto consumidor sea normalmente de escaso significado económico es la razón por la que aquél no encuentra especial atractivo en reclamar o demandar. Como señalaba a modo de ejemplo, no es fácil imaginar a un cliente entablando una acción judicial por el mal estado de una lata de conservas o por muy pequeños defectos de construcción de la vivienda que compra. Entran en juego muy diversas razones (entre ellas la falta de tradición), pero es probable que la más importante sea lo mucho que de disuasorio tiene un pleito: gastos, recogida de datos, visitas, etc.; en definitiva, incomodidades de las que no se espera gran fruto.

Parte de esas dificultades pueden verse salvadas mediante la actuación de asociaciones de consumidores. En este sentido, el artículo 20.1 
de nuestra Ley general para la defensa de los consumidores y usuarios establece la legitimación de dichas asociaciones para «representar a sus asociados y ejercer las correspondientes acciones en defensa de los mismos, de la asociación o de los intereses generales de los consumidores y usuarios». Todavía no existe una gran experiencia en cuanto al ejercicio de acciones judiciales, pero es incuestionable el impacto que esta norma tiene o puede tener en lo que se refiere a la actuación ante otras instancias, señaladamente ante la Administración pública.

Acaso no sea tan optimista el pronóstico en lo que respecta a la vía del arbitraje, establecida con buena voluntad en el artículo 31 de la Ley (y luego recordada en la Ley de arbitraje de 5 de diciembre de 1988), fórmula apta para soslayar algunos de los inconvenientes que presenta la reclamación judicial pero sobre cuya real efectividad albergo serias dudas.

Volviendo a la actuación ante los Tribunales, el primer obstáculo ha quedado ya apuntado: la dogmática procesal tradicional requiere que para ejercitar un derecho se ostente la titularidad del mismo; lo que excluye el ejercicio en favor de otros, salvo en casos muy limitada y taxativamente establecidos por la ley.

Por otro lado, los sistemas jurídicos europeos excluyen —en principio- que los efectos de una sentencia («cosa juzgada») se extiendan a quienes no fueron parte ni oídos en el juicio correspondiente. Se trata de una regla de innegable fundamento lógico (pues de otro modo podríamos vernos afectados por lo resuelto en pleitos en que no hemos intervenido), pero que en esta materia se puede tornar contra los consumidores: quienes no hubiesen reclamado por un determinado motivo contra la empresa suministradora no gozan de la ventaja de aprovecharse de lo decretado por los jueces en pleito entablado, por la misma causa, por un aislado consumidor, más diligente, más belicoso o simplemente dotado de mejores condiciones para adoptar la iniciativa que tomó (acudir al Juzgado).

Este segundo inconveniente se ha reducido en parte en la citada Ley española, dado que su artículo 10.4 declara que «serán nulas de pleno derecho y se tendrán por no puestas las cláusulas, condiciones o estipulaciones» que incumplan los requisitos de fondo y forma que en el propio precepto se establecen para los contratos cuyo objeto fuere «la oferta, promoción o venta de productos o servicios», circunstancia que desde luego constituye una facilidad para quien entabla un pleito sobre el mismo supuesto de hecho de otro anteriormente promovido por un consumidor distinto. Esta línea, aunque con mayor alcance, se había iniciado con nuestra Ley del contrato de seguro de 8 de octubre de 1980, cuyo artículo $3 .^{\circ}$, párrafo tercero, dice: «Declarada por el Tri- 
bunal Supremo la nulidad de alguna de las cláusulas de las condiciones generales de un contrato, la Administración pública competente obligará a los aseguradores a modificar las cláusulas idénticas contenidas en sus pólizas» ${ }^{6}$.

El problema, no obstante, sigue en pie en lo que se refiere a las evidentes dificultades con que cada concreto consumidor, aislado, se topa para hacer efectiva la defensa de sus intereses en vía judicial.

Nos encontramos aquí, aunque no se trate de supuestos idénticos, con lo que ocurre en relación con los llamados «intereses difusos»o «de masa», que — frente a los «intereses colectivos»— se consideran propios de formaciones sociales aún en fase de «toma de conciencia», cuya individualización se realiza a través de la relevancia de una lesión, de un perjuicio a una pluralidad de individuos que por eso se asocian para su defensa.

Los problemas que plantea la defensa de intereses como los que nos ocupan son, por un lado, la legitimación de agrupaciones de perjudicados; y por otro, el destino final de la indemnización por el daño sufrido.

Una primera solución — desde luego insuficiente- fue la de acumular en un solo pleito todas las demandas planteadas por un mismo motivo. Sin embargo, en el panorama del Derecho comparado la figura más significativa en este punto es la de la class action, procedente del mundo jurídico anglosajón, en concreto norteamericano.

Se trata de la acción ejercitada por un demandante, pero no para satisfacer su propio y exclusivo interés, sino también el de todos los que se encuentren en la misma situación. Dicho de otro modo, un único demandante reúne tras de sí cualquier reclamación similar a la suya. De alguna manera podría utilizarse la expresión de que quien demanda ante los Tribunales lo hace, no en nombre, pero sí en interés de un conjunto, en el sentido de que lo que el juez resuelva alcanza a dicho conjunto. Con ello se produce un curioso acceso a la justicia por parte de quien formalmente no entabla pleito alguno.

Ejemplo histórico en esta materia fue el del pleito que una persona interpuso contra la General Motors, alegando que él, como comprador de un determinado modelo de automóvil de dicha empresa, había sufrido el perjuicio derivado de la sustitución del motor de aquel modelo,

6 Con ello, el control judicial sobre las condiciones generales del contrato se extiende (de alguna manera) más allá de quienes hubieron sido parte en un determinado pleito (asegurador y asegurado), puesto que la declaración de nulidad hecha por el Tribunal Supremo pone en marcha el control administrativo sobre cláusulas idénticas; esto constituye una fórmula eficaz, siquiera preventivamente, respecto de los demás asegurados en cuyas pólizas figurase una cláusula igual a la anulada. 
sustitución que no había sido comunicada a los compradores del mismo. Decía actuar el demandante en nombre de otros 67.000 adquirentes del mismo automóvil, si bien la expresión «en nombre» ha de entenderse en sentido amplio, ya que no se le había conferido ninguna representación por parte de aquellos numerosos afectados. Por cierto, el conflicto terminó por vía de transacción, ya que la empresa fabricante ofreció 200 dólares de indemnización y una ampliación de la garantía por tres años en favor de cada uno de los poseedores del modelo de automóvil en cuestión. La colectividad de perjudicados, en esta hipótesis, no es una organización ya ordenada o en funcionamiento, sino que basta la existencia de una categoría de hecho, de una clase individualizada o individualizable, como sería, en el ejemplo que he citado, la condición de dueño de un determinado modelo de automóvil.

En la class action se vienen abajo postulados tradicionales en materia procesal. Cuando la demanda consiste en la petición de una indemnización, no debe tenerse en cuenta sólo el daño sufrido por quien plantea la demanda, sino el causado a la colectividad de afectados. En este tipo de acción, el demandante (class suitor) obtiene una sentencia cuyos efectos se extienden a los interesados ausentes. El único control es judicial y está encaminado a garantizar que el demandante es miembro de una class y actúa en interés de la misma. Comprobado por el juez que el class suitor protege convenientemente el interés del grupo, el Tribunal dirige una notificación individual a todos y cada uno de los miembros del grupo, en la medida en que con un esfuerzo razonable sea posible identificarlos. Con ello se pone en conocimiento de quienes no intervienen directamente en el pleito la existencia del mismo, a fin de que, entre otras cosas, puedan excusarse o separarse de las consecuencias del litigio, si lo hacen expresamente; su silencio se interpreta como aprobación. Cumplido este requisito, el «representante» del grupo aceptado por el juez actuará en nombre de la colectividad.

Nos estamos refiriendo a una figura de muy difícil encaje en nuestro Derecho. La legislación procesal española no contempla supuestos de «legitimación de grupo», que atribuyan a una persona «representación» para actuar en nombre de todos los demás afectados por el mismo motivo, aunque éstos no litiguen.

No parece que la alusión del artículo 9.2 de la Constitución a los «grupos en que se integra» el individuo sea bastante para dar carta de naturaleza entre nosotros a figuras como la class action. Está por ver qué aplicación pueden hacer los órganos jurisdiccionales del acaso más expresivo artículo 7 de la Ley Orgánica del Poder Judicial de 1 de julio de 1985, que dispone que «los Juzgados y Tribunales protegerán los derechos e intereses legítimos, tanto individuales como colectivos, sin que en ningún caso pueda producirse indefensión. Para la defensa de estos últimos intereses —añade el precepto— se reconocerá la legiti- 
mación de las corporaciones, asociaciones y grupos que resulten afectados o que estén legalmente habilitados para su defensa y promoción».

Algún autor ha querido ver en esta expresa referencia a la legitimación de grupos que resulten afectados una auténtica legitimación colectiva, a modo de reconocimiento del derecho a acudir a los Tribunales por parte de dichos grupos mediante la intervención de determinados miembros, sin necesidad de representación formal especial, alegando un interés jurídico relevante; pero no veo claro que esto pueda alcanzar a la reclamación de daños sufridos a causa de una determinada práctica empresarial o de defectos de un producto, por ejemplo. Me parece que la norma citada puede servir para justificar demandas encaminadas a una simple declaración (por ejemplo, nulidad de una cláusula, ilegitimidad de una determinada modalidad comercial, etc.), pero no encuentro en ella apoyo para dar cauce a demandas de condena, como sería la de indemnización de perjuicios.

\section{Algunos de los principales problemas técnico-jurídicos que plantea la protección del consumidor}

1. No me refiero aquí a fórmulas legales como pueden ser la adopción de criterios de presunción de culpa del empresario (con la consiguiente inversión de la carga de la prueba) o la introducción de principios, más o menos moderados, de responsabilidad objetiva por daños causados por productos o servicios defectuosos. Estos, más que «problemas», son alternativas u opciones de técnica legislativa. Sin perjuicio de que, desde luego, fórmulas como las citadas entrañen la dificultad de haber sabido valorar debidamente (antes) si su adopción se ajustaba a los datos de orden económico, tecnológico, social, etc., que han de tenerse presentes para no desequilibrar el sistema jurídico visto en su conjunto.

A lo que quiero aludir es a las dificultades que se han planteado para hacer posible, sin serio quebranto de los postulados doctrinales clásicos, que el consumidor pueda formular su demanda contra un fabricante o dispensador de servicios con el que aquél no ha contratado.

a) En primer lugar, no está de más advertir que la dotación de instrumentos jurídicos adecuados en favor del consumidor implicaba la necesidad de superar las insuficiencias de las reglas tradicionales sobre responsabilidad por vicios ocultos, en el contrato de compraventa, vigentes en los Códigos de la Europa continental y cuyo origen se encuentra en las acciones edilicias del Derecho romano. 
b) En segundo término, hace tiempo que se advirtió de la necesidad de dotar al consumidor de un régimen de acciones bien definidas y perfiladas contra el fabricante, cuando - como ocurre habitualmente- aquél no ha mantenido una relación contractual con este último. Es digno de señalarse que precisamente en este punto fue en el que hace ya años empezaron a manifestarse las primeras inquietudes jurisprudenciales y doctrinales en los países en que la materia que nos ocupa adquirió temprana efervescencia. Basta recordar en este sentido los primeros pronunciamientos judiciales norteamericanos y británicos, entonces constitutivos de una interesante denuncia sobre la insuficiencia de los criterios jurídicos clásicos y por ello, en ocasiones, de fallos auténticamente revolucionarios.

En Estados Unidos, en efecto, una de las mayores dificultades para construir técnicamente la responsabilidad civil del fabricante fue el principio jurisprudencial anglosajón de la «privity of contract» (correlativo al principio de la «relatividad de los efectos del contrato» del Derecho continental europeo, consagrado en nuestro Código civil en el artículo 1.257), por cuya virtud los contratos sólo producen efectos entre las partes que los conciertan, sin eficacia respecto a terceros, ni en favor ni en contra.

Los tribunales norteamericanos superaron este obstáculo mediante la distinción entre cosas peligrosas en sí mismas y cosas peligrosas como consecuencia de un defecto de fabricación, a partir de la cual se dio paso a la admisión de la responsabilidad del fabricante y del vendedor cuando se prueba una falta de diligencia en el proceso de fabricación o de distribución del producto. Ese deber de diligencia — se añadió- podía ser invocado por el comprador (consumidor) que no hubiera tenido relación contractual con el fabricante.

Esta orientación arranca de un famoso caso de 1916, como consecuencia de la demanda entablada por la víctima de un daño producido por el defecto de fabricación de un automóvil. La empresa fabricante no tuvo éxito en su alegación de que sus obligaciones y garantías existían tan sólo en los límites establecidos en su relación con los revendedores o distribuidores. El juez Cardozo puso de manifiesto que el fabricante de productos sustraídos a sucesivos controles tiene un deber de diligencia frente al público, con independencia de los particulares vínculos obligatorios que le unan negocialmente con cualquier persona. Un resultado dañoso previsible e imputable a un defecto del automóvil acarrea la obligación de resarcir el daño por parte de la empresa fabricante. Este debe responder frente a terceros, con independencia de las circunstancias del producto y de la particular responsabilidad contractual frente al revendedor o distribuidor.

Del mismo modo, aunque más tarde, la jurisprudencia inglesa superó el obstáculo de la «privity of contract» mediante la ficción de un 
«collateral contract» entre el fabricante y el usuario. En suma, vino a aceptarse el principio de la responsabilidad civil del fabricante frente al consumidor o usuario, sin que entre ellos existan vínculos contractuales. Por este motivo, esa responsabilidad se emplaza en Derecho inglés dentro de la extracontractual, esto es, en el llamado «law of torts» o Derecho de daños.

c) En tercer lugar, también se ha advertido desde siempre la necesidad de eliminar, o al menos de aliviar, en favor del consumidor, las reglas clásicas en materia de carga de la prueba en el proceso.

Tanto para hacer frente a esta cuestión como para resolver adecuadamente la segunda de las que hasta ahora hemos planteado, la línea doctrinal y jurisprudencial dominante ha sido la de propugnar en primer término una responsabilidad civil única, sin calificativo de contractual o extracontractual y derivada por tanto del hecho objetivo de la producción de un daño en el uso de un producto fabricado.

Por otro lado, en Estados Unidos y en Inglaterra se han mitigado las muchas dificultades de prueba que recaerían sobre el comprador, de acuerdo con los principios tradicionales de Derecho procesal, mediante la aplicación de un principio muy conocido en el Derecho anglosajón. Se trata de la regla "res ipsa loquitur», esto es, el razonamiento de que cuando las circunstancias hablan por sí solas se produce una inversión de la carga de la prueba, que hace que sea el demandado quien tenga que demostrar la falta de culpa o negligencia en su conducta.

Otro remedio ha sido el de la tendencia hacia una denominada responsabilidad objetiva en la materia, si bien el uso de esta expresión es sólo una forma de entenderse, ya que es frecuente matizarla diciendo que se trata de una responsabilidad objetiva «no absoluta»; como, por cierto, ocurre en nuestra Ley de 6 de julio de 1994 sobre responsabilidad civil por los daños causados por productos defectuosos.

El criterio de la responsabilidad objetiva fue introducido en el Derecho norteamericano por vía jurisprudencial, sobre la base de que la responsabilidad del fabricante no se funda en su «negligence», ni en una pretendida garantía expresa o tácita, sino en el simple hecho de haber puesto en el mercado un producto defectuoso.

La afirmación de una «strict liability» por parte de los tribunales norteamericanos se basa en una serie de argumentos que las sentencias suelen recoger con bastante uniformidad. El primero es el de que el interés público exige la máxima protección de la vida humana, de la salud y de la seguridad personal. La posición del consumidor es muy vulnerable, frente a la poderosa del fabricante. Este tiene la posibilidad de un control efectivo sobre la producción, desde el diseño del producto que proyecta lanzar al mercado hasta la última prueba de calidad, mientras 
que el consumidor se encuentra en general imposibilitado para apreciar los peligros del producto.

En segundo término, se argumenta que el hecho de que el fabricante ponga en el comercio un bien equivale al aseguramiento de un uso del mismo conforme a su propia naturaleza.

Por fin, se argumenta también que el fabricante se encuentra mejor situado en la estructura del mercado de bienes para distribuir el riesgo entre el público, a través de los precios y del seguro. El riesgo del evento dañoso puede ser asegurado por el fabricante y distribuido entre los consumidores, como un coste más de la actividad empresarial. El fabricante es responsable aunque no haya sido negligente en el proceso productivo, es decir, aunque se trate de un efecto fortuito, porque esta hipótesis constituye un riesgo general y constante de toda actividad de producción. Frente a tales riesgos, generales y constantes, debe afirmarse paralelamente una protección del público también general y constante. Y el fabricante es el que está en mejor situación para soportarla.

A parecida solución práctica, aunque con diferente construcción técnica, se llegó hace tiempo en países europeos de tradición jurídica romana. En Francia, por ejemplo, se solventó la dificultad que entrañaba el principio de «relatividad del contrato», y sobre todo el de la prueba de la culpa del fabricante, acudiéndose a una interesante interpretación del párrafo primero del artículo 1.384 de su Código civil. En su virtud, se estableció la responsabilidad del fabricante o vendedor como «guardián de la cosa» que viene obligado a la reparación del daño incluso si demuestra que su causa es desconocida o que no ha incurrido en culpa. Para librarse de responsabilidad ha de probar el caso fortuito, la fuerza mayor o la intervención de una causa extraña que no le sea imputable.

d) En cuarto lugar, y como contrapartida de las anteriores consideraciones, no debe olvidarse que contribuye a complicar la cuestión la razonable alegación de que el designio de dotar al consumidor de una adecuada protección no puede llevar tan lejos que se sofoque la iniciativa, el progreso (en definitiva, el desarrollo), como consecuencia de un estado de permanente alarma para fabricantes y comerciantes.

No deben olvidarse a este respecto los argumentos de fabricantes y aseguradores cuando en Estados Unidos se produjeron las primeras iniciativas jurisprudenciales y legales en el conocido proceso de tutela del consumidor vivido por aquel país. No cabe ignorar, ciertamente, que fabricantes y aseguradores manejaban razones interesadas que en ocasiones eran marcadamente «de cuerpo» o «de clase», pero tampoco es posible desconocer que algunos de sus argumentos ponían el dedo en la llaga de consideraciones de orden macroeconómico (es decir, de política económica) que un legislador atento a la realidad social y a su futuro no puede desconocer sin incurrir en temeridad o frivolidad. 
2. Las dificultades técnicas que acabamos de mencionar se vienen solventando en Europa con fórmulas como las siguientes:

De un lado, la de que una ley de protección del consumidor se estructure de forma que queden debidamente diferenciadas las reglas sobre responsabilidad contractual y sobre responsabilidad extracontractual. Es un ejemplo de esta técnica la adoptada por la Ley española de 1984, general para la defensa de consumidores y usuarios. Luego tendré oportunidad de exponer cómo se utilizó este criterio.

Una segunda posibilidad es la de que la ley protectora se desentienda de esa clásica dicotomía (responsabilidad contractual - responsabilidad extracontractual), formulando criterios de responsabilidad que desplieguen sus efectos con independencia de si entre el empresario y el consumidor ha existido o no una relación contractual. Es el caso de la Directiva del Consejo de la Comunidad Económica Europea, de 25 de julio de 1985, sobre responsabilidad por los daños causados por productos defectuosos. Por ello, es también la fórmula que adopta la Ley española de transposición de la mentada Directiva, de 6 de julio de 1994. Luego me referiré a ella, así mismo.

3. No sólo eso, sino que precisamente el ámbito de la tutela jurídica del consumidor es el que, junto a otros sectores de la «fenomenología» de los daños en general, ha servido en los últimos tiempos para poner en entredicho, si no la diferencia conceptual entre las dos clases de responsabilidad que nos ocupan, sí la ciega aceptación de algunas de las consecuencias que, como derivadas de aquella dualidad, consideramos en el pasado que eran «dogmas» insuperables.

Así lo puse de manifiesto en un trabajo anterior ${ }^{7}$. Me refería en aquel lugar a la «difuminación» de las fronteras entre responsabilidad contractual y extracontractual, advirtiendo que, en concreto en materia de consumo, el desenlace a que se ha llegado consiste en hacer tabla rasa de la distinción entre ambas clases de responsabilidad, de suerte que lo que pasa a primer término es el derecho del consumidor a ser indemnizado, sin que juegue para nada (salvo matices) la circunstancia de que la compra se haya realizado al fabricante mismo o en el último eslabón de la cadena de distribución.

7 R. DE ANGel YÁGÜEz, Puesto que ocupa el Derecho de daños en el Derecho de obligaciones, en «Estudios de Deusto», enero-junio 1995, página 35. Es el texto ampliado de la ponencia presentada por el autor en el Congreso Internacional sobre la reforma del Derecho contractual y la protección de los consumidores, celebrado en Zaragoza del 15 al 18 de noviembre de 1993. 


\begin{abstract}
Añadía entonces: «Así ocurrió ya en la Ley general para la defensa de consumidores y usuarios de 19 de julio de 1984, cuyos artículos 25 a 28 toman como punto de referencia el daño sufrido por el consumo de bienes o la utilización de productos o servicios, que se imputa indistintamente a quienes producen, importan, suministran o facilitan aquellos productos o servicios, sin particularidad alguna basada en la naturaleza de la relación entre responsable y víctima. Sólo el artículo 29 introduce un cierto factor de confusión al decir que el consumidor o usuario tiene derecho a una compensación, sobre la cuantía de la indemnización, "por los daños contractuales y extracontractuales", durante el tiempo que transcurra desde la declaración judicial de la responsabilidad hasta su pago efectivo».
\end{abstract}

\title{
IV. Las formas en que se ha articulado en Europa el «sistema» jurídico de protección del consumidor
}

1. Si he entrecomillado en el título de este apartado la palabra «sistema» es porque, en efecto, el régimen legal de protección del consumidor se ha construido y se viene construyendo en Europa no a través de leyes exclusivamente encaminadas a tal propósito, sino mediante un conjunto de disposiciones legales, del más variado rango normativo, susceptibles de ser consideradas en su conjunto, ciertamente, como un verdadero «sistema»; es decir, como una suma de reglas o principios enlazados entre sí en razón a un denominador común: el propósito de hacer que el mercado, y dentro de él el consumo, se acomode a soluciones armónicas, por las que quien adquiere bienes o utiliza servicios no sufra las consecuencias de la natural desigualdad en que se encuentra respecto al empresario que los suministra o presta.

Describiré a continuación cómo se ha articulado ese régimen tuitivo del consumidor.

2. En primer lugar, son muchas las disposiciones legales que, sin tener como objetivo primario el de la protección del consumidor, han introducido criterios o reglas que, a modo de efecto secundario o indirecto, dispensan de hecho esa tutela.

Por citar sólo unos ejemplos, menciono los siguientes en el Derecho español:

La Ley de ventas a plazos de bienes muebles, de 17 de julio de 1965, sentó principios (aunque no muchos) notoriamente movidos por el designio de favorecer a la "parte más débil», es decir, el comprador. Así, por ejemplo, se establecieron como derechos de este último el de desistir del contrato dentro de los tres días siguientes a la entrega de la 
cosa, el de anticipar el pago del precio (para aliviar la carga financiera que entraña la compra a plazos) y el de alterar la propia cadencia de los plazos por justas causas apreciadas por los Tribunales, tales como desgracias familiares, paro, larga enfermedad y otros infortunios. Todo ello, sin perjuicio de otras medidas no menos considerables (entonces), como la aparentemente insignificante de tenerse que especificar con todo detalle en el contrato el recargo o mayor precio efectivo que el hecho de comprar a plazos entraña.

Constituyó también una novedad en el mismo sentido la Ley de contrato de seguro, de 8 de octubre de 1980, con normas que ponían de manifiesto un nuevo «signo de los tiempos», como las de sus artícu$\operatorname{los} 2$ y 3 .

Innegablemente, persigue fines de protección del consumidor, siquiera de forma indirecta, también la Ley general de publicidad, de 11 de noviembre de 1988. En la medida en que se enumeran en su artículo 3 las modalidades de publicidad ilícita (cuyo régimen respectivo se contiene en artículos posteriores de la Ley), esta normativa está llamada no sólo a proteger a los empresarios respecto de las prácticas publicitarias ilícitas llevadas a cabo por otros, sino también, como decía, a tutelar el interés del consumidor. Este último suele ser, en definitiva, la víctima última de la publicidad engañosa, desleal, subliminal o contraria a la normativa rectora de la propia de determinados productos o servicios $^{8}$.

Otro tanto cabe decir de la Ley de 10 de enero de 1991 sobre competencia desleal. Es patente que una disposición sobre esta materia contempla, entre otros, «el interés privado de los empresarios, el interés colectivo de los consumidores y el propio interés público del Estado al mantenimiento de un orden concurrencial debidamente saneado». Estas son palabras textuales de la Exposición de Motivos. En ella, más adelante, y con ocasión de la mención del principio constitucional de libertad de empresa, se dice que «esta exigencia ... se complementa y refuerza por la derivada del principio de protección del consumidor, en su calidad de parte débil de las relaciones típicas de mercado, acogido por el artículo 51 del texto constitucional». Y más adelante, a su vez, la propia Exposición de Motivos reitera que la Ley «se hace portadora no sólo de los intereses privados de los empresarios en conflicto, sino también de los intereses colectivos del consumo». Y cita como particular-

8 La Exposición de Motivos de esta Ley hace explícita alusión a los «intereses implicados», advirtiendo que merece especial atención el «interés general». A todas luces, este último es el de los potenciales consumidores. 
mente ilustrativo al respecto el artículo 19, que atribuye legitimación activa para el ejercicio de las acciones derivadas de la competencia desleal a los consumidores, individual y colectivamente considerados. En su último pasaje, la misma Exposición de Motivos declara que el legislador es consciente de que la materia de la «competencia desleal» se halla muy próxima a las materias de «comercio interior» y de «tutela del consumidor», invocando de nuevo la «necesidad de reforzar la posición del consumidor como parte débil de las relaciones típicas del mercado».

3. En segundo término, se halla el que podríamos denominar «bloque normativo básico» en materia de defensa del consumidor. Es lo que, aludiendo al título de mi intervención, podría considerarse el genuino «estatuto del consumidor» en Europa.

A este respecto, y sin perjuicio de las particulares alusiones que luego haré a algunos de los cuerpos normativos que ahora cito, procede reseñar las disposiciones legales fundamentales en la materia. Adopto para ello un orden preferentemente cronológico, sin distinguir, como corresponde, entre leyes españolas en sentido estricto (las que antes he denominado "privativas») y cuerpos legales emanados de los órganos de la hoy Unión Europea.

Abrió el camino en nuestro país la Ley general para la defensa de los consumidores y usuarios, de 19 de julio de 19849. En esta Ley se establecieron las líneas generales de un sistema arbitral de consumo, que luego fue regulado en detalle por el Real Decreto de 3 de mayo de 1993.

Constituyó un hito particularmente significativo en toda esta materia la Directiva del Consejo CEE 85/374, de 25 de julio de 1985, relativa a la aproximación de las disposiciones legales, reglamentarias y administrativas de los Estados miembros en materia de responsabilidad por los daños causados por productos defectuosos. Es la que comúnmente conocemos como «Directiva sobre productos defectuosos».

Como transposición (por cierto muy tardía) de la Directiva que acabo de mencionar al Derecho español, se promulgó en nuestro país la Ley de 6 de julio de 1994, sobre responsabilidad civil por los daños causados por productos defectuosos.

La Directiva del Consejo CEE 85/577, de 20 de diciembre de 1985, versó sobre la protección de los consumidores en el caso de contratos negociados fuera de los establecimientos mercantiles.

9 En desarrollo parcial de esta Ley, se dictó el Real Decreto de 8 de marzo de 1991, por el que se aprueba el catálogo de productos, bienes y servicios a determinados efectos de dicha Ley. 
Su transposición al Derecho español se llevó a cabo mediante Ley de 21 de noviembre de 1991, del mismo nombre. La Exposición de Motivos de esta Ley española revela a las claras la finalidad específicamente tuitiva del consumidor que perseguía la Directiva y, en consecuencia, nuestra propia Ley. Dice al respecto: «La Directiva establece un conjunto de medidas de protección al consumidor por entender que, en los contratos que se celebren fuera del establecimiento del comerciante, concurren circunstancias de iniciativa de éste y de imposibilidad de comparación de la calidad y el precio de la oferta que pueden determinar la existencia de prácticas comerciales abusivas» ${ }^{10}$.

El 22 de diciembre de 1986 se promulgó la Directiva del Consejo de la CEE 87/102, relativa a la aproximación de las disposiciones legales, reglamentarias y administrativas de los Estados miembros en materia de crédito al consumo, modificada por la Directiva del Consejo de la CEE 90/88, de 22 de febrero de 1990.

Esta última Directiva fue objeto de transposición al Derecho español mediante nuestra Ley de 23 de marzo de 1995, sobre crédito al consumo.

La Directiva del Consejo de la CEE 93/13, de 5 de abril de 1993, tuvo por objeto las cláusulas abusivas en los contratos celebrados con los consumidores.

Esta Directiva está en curso de transposición al Derecho español, a cuyo fin el Gobierno ha remitido hace muy poco a las Cortes un Proyecto de Ley cuyo nombre hasta ahora es de Condiciones generales de la contratación. No obstante, a pesar de esta denominación, el Proyecto (por medio de una disposición adicional) introduce en la Ley general para la defensa de los consumidores y usuarios - la antes citada de 1984- las modificaciones oportunas para dar cabida en ella al régimen aplicable a las cláusulas abusivas en los contratos celebrados con los consumidores. Tendremos oportunidad de desarrollar este extremo más adelante, con el detalle que justifica un texto legal de tanta importancia.

La Directiva 94/47/CEE del Parlamento Europeo y del Consejo, de 26 de octubre de 1994, regula la protección de los adquirentes en lo re-

10 La propia Exposición de Motivos sintetiza los instrumentos que al efecto adoptan tanto la Directiva como la Ley española. Se manifiesta en ese lugar: «La Ley, de acuerdo con el contenido de la Directiva, define los supuestos contractuales en los que concurren las circunstancias que justifican la protección que el texto legal establece. Dicha protección se articula, por un lado, mediante la exigencia formal de la documentación del contrato o de la oferta contractual con la consecuencia obligada de reconocer al consumidor acción para anular los contratos que se celebren obviando dicho requisito y por otro, mediante el reconocimiento del derecho del consumidor a revocar el consentimiento prestado». 
lativo a determinados aspectos de los contratos de adquisición de un derecho de utilización de inmuebles en régimen de tiempo compartido (el conocido en el mundo anglosajón como «time sharing»).

La transposición al Derecho español de esta Directiva parece que va a llevarse a cabo muy pronto, puesto que recientemente se ha publicado el correspondiente Proyecto de Ley sobre derechos de aprovechamiento por turno de bienes inmuebles ${ }^{11}$.

La Directiva 97/7/CEE, del Parlamento Europeo y del Consejo, de 20 de mayo de 1997, versa sobre la protección de los consumidores en materia de contratos a distancia.

Por fin, aunque las menciones que hago no tienen propósitos de exhaustividad, no puede dejar de mencionarse la Directiva 92/59 del Consejo, de 29 de junio de 1992, relativa a la seguridad general de los productos.

También procede señalar que alguna Directiva en materia de protección del consumidor no ha alcanzado éxito todavía. Es el caso, a que antes me refería, de la propuesta de Directiva sobre la responsabilidad por servicios defectuosos.

Tomo de Gómez Calero ${ }^{12}$ la síntesis que este autor hace del régimen de responsabilidad que preveía la propuesta:

«Los artículos dedicados a la "responsabilidad" son los que contienen las normas más significativas; a saber: $a$ ) Se declara como "principio" que el prestador de servicios será responsable del daño causado por su culpa a la salud y a la integridad física de las personas o la integridad física de los bienes; la carga de la prueba de la ausencia de culpa incumbe al prestador de servicios; la mera existencia o posibilidad de un servicio más perfeccionado no constituirá de por sí culpa (artículo 1); b) La víctima deberá demostrar la existencia del daño y la relación de causalidad entre éste y la prestación del servicio (artículo 5); c) La responsabilidad no disminuye por la participación de un tercero en el acto lesivo; pero puede reducirse e incluso anularse si concurre culpa de la víctima (artículo 6); $d$ ) No se admiten cláusulas de limitación o exclusión de la responsabilidad (artículo 7); e) La obligación de indemnizar tiene carácter solidario cuando varias personas son responsables del mismo daño o en caso de "acuerdos de franquicia" (artículo 8); y $f$ ) Se prevé un plazo de cinco años para la extinción de los derechos del perjudicado; y un plazo de tres años para la prescripción de la acción de resarcimiento; ambos son ampliables si se trata de proyecto o construcción de edificios (artículos 9 y 10).»

\footnotetext{
11 Boletín Oficial de las Cortes Generales de 16 de setiembre de1997.

12 Gomez Calero: Responsabilidad civil por productos defectuosos, Madrid, 1996, páginas 32-33.
} 
El mismo autor resume de la siguiente forma las notas que caracterizaron la propuesta de Directiva. Dice: «Dos notas relevantes caracterizan a esta propuesta ...; que son: a) La responsabilidad del empresario de servicios no es objetiva, sino que se trata de una responsabilidad por culpa con inversión de la carga de la prueba; y $b$ ) este principio viene condicionado por la exigencia de una extremada diligencia al prestador de servicios, que está obligado a garantizar, en condiciones normales y razonablemente previsibles, la seguridad que cabe esperar legítimamente del servicio».

Ahora bien, lo cierto es que el 15 de enero de 1991 el Consejo de las Comunidades Europeas decidió consultar al Comité Económico y Social sobre la propuesta que nos ocupa. Este Comité rechazó el texto de la propuesta de Directiva, aduciendo entre otras cosas que su texto no responde a los deseos de los consumidores, que la propuesta no va encaminada a mejorar la relación entre clientes y profesionales prestadores de servicios y que perjudica las legítimas aspiraciones de los consumidores en materia de investigación, experiencias y riesgos en los ámbitos del Derecho, la construcción y la salud.

Por todo ello, la propuesta de Directiva en cuestión se halla hoy «en suspenso», en espera de una eventual reconsideración de sus líneas maestras.

4. Por fin, una tercera «técnica» de protección del consumidor en Europa es la constituida por lo que podríamos llamar genéricamente la «acción administrativa de control».

Me refiero, claro está, a la actividad de la Administración pública reglamentando determinados sectores de actividad empresarial, para asegurarse de la rectitud de su desempeño y de sus resultados.

Estamos en presencia de una legislación abundantísima, en la que cualquier intento de enumeración exhaustiva es casi inútil.

Tanto normas comunitarias como disposiciones legales de cada Estado (en concreto del español) llegan a regular hasta los más insignificantes detalles de la actividad empresarial en determinados sectores, para procurar - como decía - un desarrollo de la misma ajustado a la tutela del consumidor y a evitar a éste muchos de los problemas que sin esa intervención administrativa se han venido dando en el pasado, a veces con casos constitutivos de auténticos «escándalos».

Desde la actividad de las empresas de banca y crédito, hasta las de transportes, pasando por los seguros y otras muchas más, son objeto de esta acción reglamentadora de la Administración. En materia de productos, las reglas más minuciosas que uno puede suponer se hallan en la legislación europea. La fabricación de alimentos, de bebidas, de juguetes, de conservas, de electrodomésticos, de ascensores, de productos farma- 
céuticos, de insecticidas, de vehículos, de productos químicos, de productos pirotécnicos, de tabaco, etc., por citar sólo algunos ejemplos, se halla sometida a una férrea normativa administrativa, de ordinario seguida de un sistema de control por parte de las autoridades y de un régimen de sanciones. Todo ello, como decía, con el propósito de garantizar la bondad de los servicios y de los productos, evidentemente en protección del «interés general»; que, en definitiva, es el del consumidor.

Como señalaba antes, no es posible, ni ahora sería adecuada, la enumeración exhaustiva de las normas legales (casi siempre reglamentarias) que constituyen esta tercera manifestación del «sistema» de protección del consumidor.

Pero, aunque sólo sea a modo de ejemplos, cabe citar algunas de ellas.

La Ley de 29 de julio de 1988 sobre disciplina e intervención de las entidades de crédito establece, como indica su nombre, un control - desde luego severo- de las actividades bancarias en sentido amplio.

La Ley de 30 de julio de 1987, de ordenación de los transportes terrestres, constituye la base de una profusa normativa reglamentaria para gobernar este sector.

En materia de seguros, procede la cita de la Ley de 8 de noviembre de 1995, de ordenación y supervisión de seguros privados, llamada a sentar los principios en el «control» de la actividad de las empresas de este sector, actividad tan particularmente apta para poner en peligro los intereses del «contratante débil» que es el consumidor (asegurado).

He citado sectores de «servicios» de particular importancia. Pero hay otros muchos más sometidos a la «disciplina administrativa». Por ejemplo, servicios de hostelería en sentido amplio, servicios de agencias de viajes, los de educación, los sanitarios, los de construcción y venta de inmuebles, los de reparación de vehículos, los de tarjetas de pago o tarjetas de crédito, etc., son también casos significativos de presencia de la Administración pública en lo que nos viene ocupando.

Desde luego, hablo de Administración en el sentido más amplio posible, que va desde la propia de la Unión Europea hasta la municipal, pasando, en España, por la Administración Central del Estado y por la de las Comunidades Autónomas, esto último en virtud del peculiar régimen de autonomías establecido en nuestra Constitución de 1978.

\section{La Ley (española) general para la defensa de los consumidores y usuarios, de 19 de julio de 1984}

Me ocupo ahora brevemente de la Ley precursora en esta materia en Derecho español. 
1. La Ley a que me refiero fue producto, desde luego, de una inquietud doctrinal en materia de protección del consumidor, compartida por los poderes públicos. Pero parece claro que el detonante de su promulgación fue un conocido caso (en verdad, un escándalo) que conmocionó a la opinión pública española. Fue el llamado «caso del aceite de colza», consistente en pocas palabras en que muchísimas personas sufrieron intoxicaciones (con no pocos fallecimientos) como consecuencia de haber ingerido aceite desnaturalizado, parece que destinado a usos industriales.

Sin perjuicio de lo que en seguida diré sobre los rasgos generales de esta Ley, procede destacar desde ahora que se encuentra derogada en lo que se refiere a la responsabilidad por daños causados por productos defectuosos, en virtud de la muy posterior promulgación de la Ley de este último nombre, de 6 de julio de 1994, que luego mencionaré también.

Aunque la Ley española de 1984 alcanzaba a la tutela del consumidor en cuanto a productos y servicios, la Ley de 1994, como consecuencia de ser adaptación o transposición al Derecho español de la Directiva comunitaria sobre productos de 25 de julio de 1985, declaró en su disposición adicional primera que los artículos 25 a 28 de la Ley de 1984 no serían aplicables ya a la responsabilidad civil por daños causados por los productos defectuosos definidos en el artículo 2 de la propia Ley de 1994.

Dicho de otro modo, la Ley a que ahora aludo (la de 1984) sólo es aplicable, en esos artículos 25 a 28 (los que tratan sobre responsabilidad), al caso de los servicios defectuosos y a los productos no incluidos en la Ley de $1994^{13}$.

Quiere decir que la Ley tiene todavía un amplio ámbito, dándose la particularidad de que los daños derivados de servicios sí han sido objeto de regulación genérica en Derecho español (precisamente en esta Ley), aunque no en el régimen comunitario. Me remito a la ya descrita frustración de la propuesta de Directiva sobre esta última materia.

En esta Ley, nutrida de disposiciones que podríamos denominar «de carácter administrativo» (en la medida en que afectan a la acción de la Administración pública en materia de consumo), conviene distinguir, desde un punto de vista de Derecho privado estricto, entre la regulación calificable como «contractual» y la relativa a la «responsabilidad» por servicios o productos defectuosos.

13 Me remito a lo que luego se dirá sobre el concepto de «producto» en el artículo 2 de la Ley de 1994 en cuestión. 
La primera de esas dos materias se halla en el Capítulo III, bajo la equívoca rúbrica de «protección de los intereses económicos y sociales». En realidad, se trata de normas sobre relaciones contractuales entre empresario y consumidor, con mención preferente de las cláusulas, condiciones o estipulaciones que, con carácter general, se apliquen a la oferta, promoción o venta de productos o servicios (me refiero sobre todo al artículo 10).

Por lo que respecta a la «responsabilidad» en sentido amplio, es materia regulada en el Capítulo VIII, bajo la rúbrica de «Garantías y responsabilidades» (artículos 25 a 31).

A continuación expongo los rasgos principales de la disposición legal en que nos encontramos.

\section{Campo de aplicación de la Ley}

La Ley española tiene como objeto la protección del consumidor en todos sus aspectos. De forma que la introducción de un nuevo régimen de responsabilidad civil por daños del producto es sólo uno de los instrumentos que la Ley establece dentro de aquel objetivo más amplio.

El concepto de consumidor o usuario se formula con gran amplitud, al decirse que lo son «las personas físicas o jurídicas que adquieren, utilizan o disfrutan, como destinatarios finales, bienes muebles o inmuebles, productos, servicios, actividades o funciones, cualquiera que sea la naturaleza pública o privada, individual o colectiva de quienes los producen, facilitan, suministran o expiden» (artículo 1. ${ }^{\circ} .2$ ).

La expresión «destinatarios finales» pone de relieve que la protección legal se endereza a favor del consumidor o usuario en última instancia, no de quienes profesionalmente adquieran o utilicen bienes o servicios con el fin de integrarlos en procesos de producción, transformación, comercialización o prestación a terceros. Por ejemplo, podrá ampararse en sus preceptos quien adquiere en una tienda una caja de galletas en mal estado, pero no el comerciante que ha comprado al fabricante o mayorista una partida de cajas para la venta en su establecimiento.

\section{Régimen de responsabilidad por productos o servicios}

La Ley establece en su artículo 25 un principio que, a primera vista, parece consagrar la responsabilidad objetiva plena por la que la doctrina llama «puesta en el mercado de un producto defectuoso», pues dice que «el consumidor y el usuario tienen derecho a ser indemniza- 
dos por daños y perjuicios demostrados que el consumo de bienes o la utilización de productos o servicios les irroguen, salvo que aquellos daños y perjuicios estén causados por su culpa exclusiva o por la de las personas de las que deban responder civilmente».

Pero esta norma exige los matices que derivan de los artículos 26 y 28.

2.1. El artículo 26 se acoge al sistema tradicional de responsabilidad, en el sentido de que se responde cuando hay alguna culpa del daño producido.

Dice el precepto que las acciones u omisiones de quienes producen, importan, suministran o facilitan productos o servicios determinantes de daños o perjuicios a consumidores o usuarios darán lugar a la responsabilidad de aquéllos, a menos que conste o se acredite que se han cumplido debidamente las exigencias y requisitos reglamentariamente establecidos y los demás cuidados y diligencias que exige la naturaleza del producto, servicio o actividad.

2.2. Es el artículo 28 el que establece la verdadera novedad en esta materia al introducir lo que para unos es una responsabilidad objetiva plena y otros llaman responsabilidad por riesgo creado, es decir, la que se asume por el solo hecho de poner en el mercado bienes o servicios susceptibles por su naturaleza de ser causa de peligro.

En efecto, su apartado 1 dispone que se responderá de los daños y perjuicios originados en el correcto uso y consumo de bienes y servicios cuando por su propia naturaleza o estar así reglamentariamente establecido, incluyan necesariamente la garantía de niveles determinados de pureza, eficacia o seguridad en condiciones objetivas de determinación y supongan controles técnicos, profesionales o sistemáticos de calidad, hasta llegar en debidas condiciones al consumidor o usuario. Añadiendo el apartado 2 que en todo caso están sometidos a esta forma de responsabilidad los productos alimenticios, los de higiene y limpieza, cosméticos, especialidades y productos farmacéuticos, servicios sanitarios, de gas y electricidad, electrodomésticos y ascensores, medios de transporte, vehículos a motor y juguetes y productos dirigidos a los niños.

Es claro que el criterio de imputación de responsabilidad es el mero hecho de que el consumidor sufra el daño, sin que juegue para nada el que haya mediado negligencia o no del fabricante o comerciante. En una palabra, el consumidor sólo debe probar el daño y que éste es consecuencia del bien o servicio de que se trate en cada hipótesis.

2.3. La Ley española no prevé el caso de concurrencia de culpa con la víctima, como sería la hipótesis de un producto defectuoso y que además se utiliza indebidamente por el consumidor. 
Los daños indemnizables, a la luz de la generalidad del artículo 25 , serán los de todo orden, es decir, tanto materiales como personales, y dentro de éstos los de carácter moral.

2.4. Es importante señalar que el artículo $2 .^{\circ} .3$ de la Ley declara nula la renuncia de los derechos que ella establece en favor de los consumidores y usuarios en la adquisición y utilización de bienes o servicios.

Además, el artículo 10, en su apartado 1, excluye los siguientes posibles elementos de defensa previa del empresario:

a) Las limitaciones absolutas de responsabilidad y las relativas a utilidad o finalidad esencial del producto o servicio.

Este texto, interpretado literalmente, parece dar cabida a la cláusula de limitación parcial o disminución de responsabilidad.

b) La inversión de la carga de la prueba en perjuicio del consumidor o usuario.

c) La imposición de renuncias a los derechos del consumidor y usuario reconocidos en la Ley. Lo que es una reiteración de la norma antes citada del artículo $2 .^{\circ} .3$.

2.5. Por otro lado, en ningún caso responde el fabricante o comerciante cuando el daño sea culpa exclusiva de la víctima (artículo 25) o cuando suceda fuera de las normas del «correcto uso y consumo» de los bienes o servicios (artículo 28).

\section{Las vías de indemnización}

El instrumento fundamental de resarcimiento del consumidor o usuario dañado por un producto defectuoso es, naturalmente, la acción judicial de que aquél se halla dotado frente a quien o quienes están sujetos al deber de indemnizar, que luego identificaremos.

La regla general, por tanto, y salvadas las particularidades en cuanto a la extensión del concepto de sujeto responsable y régimen de responsabilidad agravada o «por riesgo creado» a que me he referido, es la genérica que obliga a responder por daño contractual o extracontractual según el Código civil. Daño contractual es el que puede invocar quien está vinculado por un contrato con el causante directo del daño. El daño extracontractual existe cuando entre el sujeto responsable y el consumidor perjudicado no ha mediado contrato alguno.

Una particularidad de la Ley en cuanto a la legitimación para demandar judicialmente es la de que ostentan acción las asociaciones de consumidores y usuarios, que podrán «representar a sus asociados y 
ejercer las correspondientes acciones en defensa de los mismos, de la asociación o de los intereses generales de los consumidores y usuarios» (artículo 20.1).

Por otro lado, el artículo 29 establece un instrumento de reparación por la duración del eventual pleito derivado de esta responsabilidad de productos, al decir que el consumidor o usuario tiene derecho a una compensación, sobre la cuantía de la indemnización, por los daños contractuales o extracontractuales durante el tiempo que transcurra desde la declaración final de responsabilidad hasta su pago efectivo. Pero según el apartado 2 de dicho artículo, parece que esa reparación es la general de pago de intereses a cargo del condenado a indemnizar, desde que recayó la primera sentencia que estableció su condena.

Dentro de este capítulo, merece señalarse que el artículo 31 prevé un sistema de resolución de conflictos que evite la necesidad de acudir a los Tribunales. En efecto, se dispone que el Gobierno establecerá un sistema arbitral que, sin formalidades especiales, atienda y resuelva con carácter vinculante y ejecutivo para ambas partes las quejas o reclamaciones de los consumidores o usuarios, siempre que no concurra intoxicación, lesión o muerte, ni existan indicios racionales de delito, sin perjuicio de la protección administrativa y judicial, de acuerdo con el artículo 24 de la Constitución. Los órganos de arbitraje estarán integrados por representantes de los sectores interesados, de las organizaciones de consumidores y usuarios y de las Administraciones públicas dentro del ámbito de sus competencias. Como es obvio, el sometimiento a este arbitraje será voluntario, exigiendo la Ley el requisito de que dicho sometimiento conste por escrito (apartado 2).

\section{Responsabilidad solidaria}

El artículo 27.2 de la Ley dispone que «si a la producción de daños concurrieren varias personas, responderán solidariamente ante los perjudicados».

El mismo precepto de la Ley añade, por otra parte, que en estos casos de responsabilidad solidaria «el que pagare al perjudicado» tendrá derecho a repetir de los otros responsables, según su participación en la causación de los daños.

\section{El seguro obligatorio}

Como es sabido, cuando una ley establece la fórmula de la responsabilidad objetiva, es habitual que sea la propia ley la que disponga el 
adecuado instrumento de atenuación de las consecuencias de dicha fórmula. $Y$ este instrumento es de ordinario el seguro obligatorio, por cuya virtud el eventual responsable traslada a la aseguradora las en buena medida extraordinarias consecuencias de su actuación.

Pues bien, siguiendo la línea de lo que ha ocurrido en otros sectores de actividad en que se ha establecido esta fórmula de responsabilidad (automóvil, navegación aérea, caza, etc.), el artículo 30 de ley que nos ocupa dice que el Gobierno adoptará las medidas o iniciativas necesarias para establecer un sistema obligatorio de seguro y fondo de garantía que cubran, para sectores determinados, los riesgos de intoxicación, lesión o muerte derivados del mal estado de los productos, servicios o actividades a que se refiere el artículo 28.

\section{La Directiva europea sobre responsabilidad por los daños causados por productos defectuosos y la Ley española sobre la misma materia}

\section{La Directiva de las Comunidades Europeas}

El 25 de julio de 1985, el Consejo de las Comunidades Europeas promulgó una «directiva» sobre «aproximación de las disposiciones legislativas, reglamentarias y administrativas de los Estados miembros en materia de responsabilidad por hecho de los productos defectuosos».

Responde esta disposición a la necesidad de acomodar las legislaciones internas de cada Estado miembro a unos principios - los contenidos en la propia Directiva- uniformes u homogéneos, a cuyo fin (como corresponde a una norma de esta naturaleza) se establece en su artículo 19 que los Estados promulgarán en el plazo de 3 años a partir del 30 de julio de 1985 las disposiciones legislativas, reglamentarias y administrativas necesarias para llevar a cabo dicha acomodación.

De la Directiva conviene destacar los siguientes extremos:

El artículo $1 .^{\circ}$ formula la regla básica de que «el productor es responsable del daño causado por un defecto de su producto».

Por «producto» se entiende todo bien mueble, con excepción de las materias primas agrícolas y los productos de la caza, aunque se haya incorporado a otro bien mueble o a un inmueble. Se incluye la electricidad (artículo 2..$^{\circ}$.

El artículo 14 precisa que la Directiva no se aplica a los daños resultantes de accidentes nucleares y que estén cubiertos por convenciones internacionales ratificadas por los Estados miembros. 
Siempre a los efectos de la Directiva, por «productor» se entiende el fabricante de un producto terminado, el productor de una materia prima o el fabricante de un elemento componente, así como todo aquel que se presente como productor, poniendo sobre el producto su nombre, su marca u otro signo distintivo (artículo $3 .^{\circ}$ ).

El mismo artículo $3 .^{\circ}$ dispone que, sin perjuicio de la responsabilidad del productor, toda persona que importe un producto en la Comunidad, sea por compraventa, arrendamiento, leasing u otra forma de distribución en el marco de una actividad comercial, se considera productor y responde por el mismo título que éste. Se trata de una norma muy digna de tenerse en cuenta, por su extraordinario alcance. Y añade el mismo artículo que, si el productor no puede ser identificado, el suministrador será considerado como tal, a menos que indique a la víctima, en un plazo razonable, la identidad del productor o de quien le ha suministrado a él mismo el producto. Esta regla se aplica al producto importado, si no se indica la identidad del importador, aunque se señale la identidad del productor.

Está claro que las anteriores normas tienen la finalidad de proteger al consumidor, permitiéndole saber contra quién, al menos, puede reclamar y haciéndole posible demandar judicialmente dentro de la Comunidad.

La víctima del daño debe probarlo, así como el defecto del producto y la relación de causalidad entre uno y otro (artículo $4 .^{\circ}$ ).

En el caso de que varias personas sean responsables del mismo daño, su responsabilidad es solidaria, sin perjuicio de las disposiciones del Derecho nacional relativas al reembolso (artículo 5. ${ }^{\circ}$ ).

El apartado 1 del artículo $6 .^{\circ}$ determina que un producto es defectuoso cuando no ofrece la seguridad que de él se puede legítimamente esperar teniendo en cuenta las circunstancias y sobre todo la presentación de producto, el uso que del producto puede esperarse razonablemente y el momento de puesta en circulación del mismo.

$\mathrm{Y}$ el apartado 2 puntualiza que un producto no puede ser considerado como defectuoso por el solo hecho de que otro más perfeccionado haya sido puesto en circulación con posterioridad.

De acuerdo con el artículo $7 .^{\circ}$, el productor no responde si prueba: $a$ ) que él no puso en circulación el producto; $b$ ) que, teniendo en cuenta las circunstancias, debe estimarse que el defecto que causó el daño no existía en el momento en que se puso el producto en circulación por su parte o que se originó con posterioridad; c) que el producto no ha sido fabricado para la venta o cualquier otra forma de distribución con fines económicos, y que no lo fabricó ni distribuyó en el marco de su actividad profesional; $d$ ) que el defecto se ha debido a la conformidad del 
producto con reglas imperativas dictadas por los poderes públicos; $e$ ) que el estado de los conocimientos científicos y técnicos en el momento de la puesta en circulación del producto por él —el productor- no le permitía descubrir la existencia del defecto; $f$ ) si se trata del fabricante de un elemento componente de un producto, que el defecto es imputable a la concepción del producto del que ese elemento forma parte, o a las instrucciones dadas por el fabricante del producto (terminado).

El artículo $8 .^{\circ}$ advierte que, sin perjuicio de las disposiciones de las leyes de cada Estado sobre el derecho a resarcirse o ser reembolsado, la responsabilidad del productor no se reduce cuando el daño es causado conjuntamente por defecto del producto y por la intervención de un tercero, añadiéndose, sin embargo, en el apartado 2 del mismo artículo, que la responsabilidad del productor puede ser reducida o suprimida, en atención a las circunstancias, cuando el daño es causado conjuntamente por un defecto del producto y por culpa de la víctima o de persona de la que la víctima debe responder.

La Directiva entiende por «daño» la muerte o lesiones corporales, así como el causado a una cosa o su destrucción — distinta de la del producto defectuoso mismo- con una deducción por franquicia de 500 ecus (unidad de cuenta de la Comunidad), siempre que la cosa en cuestión sea de un tipo normalmente destinado al uso o al consumo privados y haya sido utilizada por la víctima principalmente en esas funciones de uso o consumo.

Se deja a salvo el Derecho de cada Estado en punto a daños inmateriales, esto es, daños morales (todo ello, en el artículo 9. ${ }^{\circ}$ ).

Se establece como plazo de prescripción el de 3 años a contar del momento en que el demandante (el perjudicado) tuvo o debió tener conocimiento del daño, del defecto del producto y de la identidad del productor. Y se deja al Derecho de cada Estado lo correspondiente a la suspensión e interrupción de la prescripción (artículo 10).

El artículo 11 establece que los Estados miembros dispondrán en su legislación que los derechos otorgados a la víctima duran hasta la expiración del plazo de 10 años a contar de la fecha en que se puso en circulación el producto, salvo que en ese plazo se haya entablado reclamación judicial por la víctima.

Para evitar abusos por parte de los productores, se dispone que la responsabilidad de éstos no puede ser limitada o excluida por cláusulas limitativas o de exención de tal responsabilidad (artículo 12).

Por fin, el artículo 13 advierte que la Directiva no afecta a los derechos de que la víctima pueda hacer uso por vía de responsabilidad contractual o extracontractual o a causa de un régimen especial de respon- 
sabilidad que exista en el momento en que la Directiva misma se notifique a cada Estado. Piénsese, por ejemplo, en que hay países en que existen reglas especiales sobre daños por productos farmacéuticos, sobre los derivados de la construcción, etc.

2. La Ley española de responsabilidad civil por los daños causados por productos defectuosos

El 6 de julio de 1994 se promulgó en España la Ley de responsabilidad civil por los daños causados por productos defectuosos.

Esta Ley tuvo por objeto llevar a cabo la adaptación del Derecho español a la Directiva sobre la materia de la entonces Comunidad Económica Europea, de 25 de julio de 1985. Se promulgó con un considerable retraso respecto al plazo de tres años que al efecto había establecido la norma comunitaria y su redacción fue objeto de un largo y complejo proceso de elaboración, debido en buena parte a las discrepancias doctrinales planteadas al respecto.

La Ley, como corresponde a su naturaleza, recoge los principios y criterios de la Directiva comunitaria.

Considero oportuno resumir los principales rasgos de la Ley en cuestión. Pueden formularse así:

1. Se instaura un régimen de responsabilidad objetiva, aunque no absoluta, como puntualiza la exposición de motivos de la Ley.

Es responsabilidad objetiva, porque el fabricante responde - como establece el artículo 1- de los daños causados por los defectos de los productos que fabrique. No hay ninguna alusión a la culpa, lo que significa que el criterio de imputación no es ella, sino la efectiva producción del daño.

No obstante, la responsabilidad objetiva no es absoluta, porque el fabricante se ve exonerado de responsabilidad si prueba cualquiera de las circunstancias del artículo 6, esto es:

a) Que no había puesto en circulación el producto.

b) Que, dadas las circunstancias del caso, es posible presumir que el defecto no existía en el momento en que se puso en circulación el producto.

c) Que el producto no había sido fabricado para la venta o cualquier otra forma de distribución con finalidad económica, ni fabricado, importado, suministrado o distribuido en el marco de una actividad profesional o empresarial.

d) Que el defecto se debió a que el producto fue elaborado conforme a normas imperativas existentes. 
Y por fin, $e$ ), que el estado de los conocimientos científicos y técnicos existentes en el momento de la puesta en circulación no permitía apreciar la existencia del defecto. Esta última causa de exoneración de responsabilidad, sin embargo, no es aplicable en el caso de medicamentos, alimentos o productos alimentarios destinados al consumo humano.

He de señalar que hasta ahora, para simplificar, me he referido exclusivamente al fabricante (como lo haré de ahora en adelante), pero no sin dejar de advertir que el «principio general» del artículo 1 de la Ley incluye a los fabricantes y a los importadores.

El apartado 2 del mismo artículo 4 dice que se entiende por importador quien, en el ejercicio de su actividad empresarial, introduce un producto en la Unión Europea para su venta, arrendamiento, arrendamiento financiero o cualquier otra forma de distribución.

Pero, como decía antes, en mi exposición utilizaré normalmente la sola expresión de «el fabricante».

2. Otra particularidad de la Ley consiste en la delimitación de su «ámbito de protección», puesto que el régimen de responsabilidad previsto en la misma comprende los supuestos de muerte y las lesiones corporales, así como los daños causados en cosas distintas del propio producto defectuoso, siempre que la cosa dañada se halle objetivamente destinada al uso o consumo privados y en tal concepto haya sido utilizada principalmente por el perjudicado.

3. Las personas responsables del mismo daño por aplicación de la Ley lo serán solidariamente (artículo 7).

4. Según el artículo 8, la responsabilidad del fabricante o importador no se reducirá cuando el daño sea causado conjuntamente por un defecto del producto y por la intervención de un tercero.

5. Sin embargo, la culpa del perjudicado (o de una persona de la que éste deba responder civilmente) puede ser causa de exención o reducción de la responsabilidad del fabricante, si el daño causado fuera debido conjuntamente a un defecto del producto y a aquella culpa (artículo 9).

6. Otra regla digna de mención es la del artículo 15, por cuya virtud las acciones reconocidas en la Ley no afectan a otros derechos que el perjudicado pueda tener como consecuencia de la responsabilidad contractual o extracontractual del fabricante.

7. Se establece, para la prescripción de la acción de reparación de los daños y perjuicios previstos en la Ley, un plazo hasta ahora desco- 
nocido en el Derecho español, es decir, el de tres años, inferior al común de la responsabilidad contractual (quince años) y superior al de la responsabilidad extracontractual (un año).

8. Conforme al artículo 14 , son ineficaces frente al perjudicado las cláusulas de exoneración o limitación de la responsabilidad civil prevista en la Ley.

9. Todo ello, por otra parte, sobre la base del ámbito objetivo de tutela que viene dado por el artículo 2, al definir el «concepto legal de producto». Se dice en ese lugar que, a los efectos de esta Ley, se entiende por producto todo bien mueble, aun cuando se encuentre unido o incorporado a otro bien mueble o inmueble, excepto las materias primas agrarias y ganaderas y los productos de la caza y de la pesca que no hayan sufrido transformación inicial. El apartado 2 del mismo artículo dispone que se consideran productos el gas y la electricidad.

10. La responsabilidad deriva de haber puesto en circulación el producto defectuoso que causó el daño, motivo por el que la Ley (artículo 3) se cuida de definir qué se entiende por tal. Dice ese precepto:

«1. Se entenderá por producto defectuoso aquel que no ofrezca la seguridad que cabría legítimamente esperar, teniendo en cuenta todas las circunstancias y, especialmente, su presentación, el uso razonablemente previsible del mismo y el momento de su puesta en circulación.

2. En todo caso, un producto es defectuoso si no ofrece la seguridad normalmente ofrecida por los demás ejemplares de la misma serie.

3. Un producto no podrá ser considerado defectuoso por el solo hecho de que tal producto se ponga posteriormente en circulación en forma más perfeccionada.»

11. El artículo 5 establece el régimen de la prueba, diciendo: $« E l$ perjudicado que pretenda obtener la reparación de los daños causados tendrá que probar el defecto, el daño y la relación de causalidad entre ambos» ${ }^{14}$.

14 Sobre este último extremo traté con algún detalle en DE ANGEL YÁGÜEZ, Responsabilidad por productos defectuosos. Reflexiones en torno a la carga de la prueba, «Estudios de Deusto», enero-junio 1996, páginas 9 a 53. Es desarrollo de la ponencia expuesta por el autor en el II Congreso Internacional de Derecho de daños, celebrado en la Facultad de Derecho y Ciencias Políticas de la Universidad de Lima durante los días 16 a 19 de setiembre de 1996. 


\section{El proyecto de Ley español sobre Condiciones Generales de la Contratación. Régimen (añadido) de las cláusulas abusivas en los contratos celebrados con consumidores}

\section{Introducción: justificación del Proyecto y aspectos de técnica legislativa}

El Boletín Oficial de las Cortes Generales de 5 de setiembre de $1997^{15}$ publicaba el acuerdo de la Mesa de la Cámara de encomendar a la Comisión de Justicia e Interior, por el procedimiento de urgencia y con competencia legislativa plena, la aprobación del Proyecto de Ley sobre Condiciones Generales de la Contratación (en adelante, en ocasiones, LCGC) que al efecto se reproducía.

La Exposición de Motivos comienza diciendo que la Ley proyectada tiene por objeto la transposición de la Directiva 93/13/CEE, del Consejo, de 5 de abril de 1993, sobre condiciones abusivas en los contratos celebrados con los consumidores, así como la regulación de las condiciones generales de la contratación. Añade el preámbulo que se ha optado por llevar a cabo la incorporación de la Directiva citada mediante una Ley de Condiciones Generales de la Contratación que, al mismo tiempo, a través de una disposición adicional, modifique el marco jurídico preexistente de protección al consumidor, constituido por la Ley 26/1984, de 19 de julio, General para la Defensa de los Consumidores y Usuarios (en lo sucesivo, a veces, LCU).

Como cuestión previa al análisis de la Ley proyectada, merece alguna atención, a mi juicio, la contemplación de la fórmula de técnica legislativa que el Proyecto adopta.

A este respecto, hay que tener presente que, como advierte la Memoria del propio Proyecto, la idea inicial del Gobierno fue la de llevar a cabo la transposición de la citada Directiva mediante el sistema de reformar en lo oportuno (se supone que más que modificarla era ampliarla) la LCU. A tal fin, la Secretaría General Técnica del Ministerio de Justicia había elaborado un Anteproyecto.

Pero en definitiva se ha optado por cambiar de orientación. En efecto, el Proyecto sigue la fórmula justamente contraria a la prevista, es decir, la de promover una Ley de Condiciones Generales de la Contratación que, además de regular la materia que el propio nombre revela, modifique la referida LCU en lo relativo a las cláusulas contractuales abusivas.

15 Congreso de los Diputados, VI Legislatura, Serie A: Proyectos de Ley, número 78-1. 
Conviene hacer memoria de que el propósito de introducir en nuestro ordenamiento una Ley sobre condiciones generales de la contratación data de hace bastantes años. Recuérdese que ya en 1988 se publicó $^{16}$ un borrador de Anteproyecto de Ley sobre Condiciones Generales de la Contratación, realizado por la Comisión General de Codificación ${ }^{17}$.

Por otro lado, era necesario llevar a cabo la transposición de la Directiva sobre cláusulas abusivas en los contratos celebrados con consumidores, puesto que su artículo 10 dispuso que los Estados miembros de la Comunidad Económica Europea «adoptarán las disposiciones legales, reglamentarias y administrativas necesarias para dar cumplimiento a lo establecido en la presente Directiva, a más tardar, el 31 de diciembre de 1994». Es decir, ha vencido ampliamente el plazo conferido para la transposición.

De ahí, como decía, que se haya optado por la fórmula legislativa de una Ley única, con los dos contenidos a que vengo refiriéndome; y siguiendo, como dice la Memoria del Proyecto, el dictamen del Consejo de Estado.

\section{Consideraciones previas sobre el contenido de la Ley proyectada}

Hechas estas consideraciones previas, procede entrar en un análisis general (en lo que respecta a su contenido) de la Ley proyectada.

Con independencia de su estructura formal, cumple advertir que ese contenido se cifra en tres grandes bloques:

En primer lugar, la reglamentación propiamente dicha de las condiciones generales de la contratación, materia a la que, como antes señalaba, se dedica el texto «en artículos», que son veintitrés, sistematizados u organizados en siete capítulos.

En segundo término, la disposición adicional primera introduce ciertas modificaciones en la LCU, de las cuales las más significativas son: la nueva redacción del artículo 10, la adición de un nuevo artículo 10 bis y la incorporación de una disposición adicional primera que, a su vez, es desarrollo del citado nuevo artículo 10 bis.

16 En el suplemento del Boletín de Información del Ministerio de Justicia de 15 de enero de aquel año.

17 Con posterioridad se elaboró otro Anteproyecto de Ley. Lo tomo de LASARTE AlvarEZ, Principios de Derecho civil, tomo tercero, Madrid, 1994, páginas 85 y siguientes. Este Anteproyecto fue «revisión» del que se acaba de mencionar y lo citaré en lo sucesivo como «segundo Anteproyecto», aunque el ordinal pueda no ser del todo riguroso, pues ignoro si hubo otros anteriores o posteriores. Este «segundo Anteproyecto» fue de 1992, por lo que parece. 
En tercer lugar, merece una mención específica (por la importancia que, incluso desde el punto de vista «cuantitativo», le atribuye el Proyecto) la modificación de la Ley Hipotecaria, cuyos artículos 222, 233, 253 y 258 reciben una nueva redacción. Es obvio que el Proyecto «aprovecha la ocasión» para reforzar las garantías del que podríamos llamar «consumidor de servicios registrales». El apartado IX de la Exposición de Motivos de la Ley así lo dice.

\section{Régimen de las condiciones generales de la contratación}

Paso ahora al desarrollo de la reglamentación de las condiciones generales de la contratación en el Proyecto.

\subsection{Rasgos generales}

Al margen también de la estructura formal del articulado, pongo de relieve los siguientes extremos:

a) La Ley, en primer término, define las condiciones generales de la contratación, en la línea de lo que habían venido haciendo los borradores de Anteproyecto antes mencionados.

b) Se determina el ámbito territorial de la Ley.

c) Se establece qué contratos quedan excluidos de la aplicación de la Ley.

d) Se adopta la fórmula de disponer, en sendos preceptos, cuándo unas cláusulas deben considerarse «incorporadas» al contrato y cuándo no.

e) Se introducen reglas de interpretación específicas para las condiciones generales.

f) La «ineficacia» de ciertas condiciones generales se articula, en favor del contratante adherente, mediante dos formas de sanción. Una de ellas es la nulidad de pleno derecho y otra la llamada «no incorporación al contrato». Disponiéndose, al efecto, las consecuencias jurídicas que derivan de ambos tipos de sanción. ción.

g) Se crea un Registro de Condiciones Generales de la Contrata-

h) Se instauran tres acciones nuevas, que se denominan «colectivas» y que son la de cesación, la de retractación y la declarativa.

Respecto al ejercicio de estas acciones, la Ley dispone reglas sobre competencia material y tramitación del proceso; en punto a competencia territorial; sobre legitimación activa y pasiva; acerca de la prescripción; y, por fin, en torno a los efectos de la sentencia dictada en cada uno de esos tres tipos de acciones. 
i) Se introducen reglas especiales de publicidad de las sentencias dictadas, tanto en los procedimientos «individuales» como en los «colectivos».

j) Se adoptan nuevas reglas de información sobre las condiciones generales, a cargo de Notarios, Registradores de la Propiedad y Mercantiles y Corredores de Comercio.

k) Por fin, se dispone un régimen sancionador también especial.

\subsection{Concepto de condiciones generales de la contratación}

Como parecía obligado, el Proyecto suministra un concepto o definición de condiciones generales de la contratación. Lo hace en su artículo 1, que dice:

«Artículo 1. Ambito objetivo

1. Son condiciones generales de la contratación las cláusulas predispuestas cuya incorporación al contrato sea exclusivamente imputable a una de las partes, con independencia de la autoría material de las mismas, de su apariencia externa, de su extensión y de cualesquiera otras circunstancias, habiendo sido redactadas con la finalidad de ser incorporadas a una pluralidad de contratos o declaraciones jurídicamente relevantes.

2. El hecho de que ciertos elementos de una cláusula aislada se hayan negociado individualmente no excluirá la aplicación de esta Ley al resto del contrato.

3. El profesional que afirme que una determinada cláusula ha sido negociada individualmente, asumirá la carga de la prueba.»

Me parece oportuno acudir a la Memoria del Proyecto para contemplar de qué forma se ha razonado para definir qué se entiende por condiciones generales de la contratación. En ese lugar se dice:

«Las condiciones generales son, ante todo, cláusulas que van a formar parte del contenido de un contrato.

Ahora bien, son cláusulas que se caracterizan por la concurrencia de las siguientes circunstancias:

a) Predisposición por una de las partes contratantes.

b) Ausencia de negociación individual. Toda cláusula no negociada individualmente no siempre es condición general, ya que puede tratarse de un contrato de adhesión particular. Sin embargo, la afirmación inversa siempre se cumple: toda condición general implica predisposición, y en consecuencia, no negociación individual de la cláusula.

c) Que esté destinada a una pluralidad de contratos. 
Estos requisitos (carácter contractual, predisposición que excluye la negociación individual y finalidad de incorporarse a una pluralidad de contratos) se recogen en el artículo $1 .^{\circ}$ del Proyecto».

Hasta aquí, el texto de la Memoria.

En relación con el extremo que ahora nos ocupa, es decir, el del ámbito subjetivo de las condiciones generales de la contratación, la Memoria del Proyecto se refiere a la discusión doctrinal al respecto, mencionando la opinión de DíEZ-PICAZO como representativa de la idea de que el adherente en las condiciones generales puede ser también un empresario o profesional.

Por ello, la propia Memoria señala que el Proyecto distingue dos ámbitos distintos, según se trate de condiciones generales o de cláusulas abusivas:

a) tratándose de condiciones generales, el Proyecto de Ley no hace salvedad alguna, por lo que son aplicables también a las relaciones contractuales entre empresarios y profesionales, y no sólo a las relaciones entre éstos y los consumidores;

b) tratándose de cláusulas abusivas, la regulación se mantiene en sede de la legislación sobre protección al consumidor, porque se entiende que sólo cabe regular específicamente el desequilibrio contractual cuando existe un consumidor.

\subsection{Ambito territorial de la Ley}

El Proyecto también se ocupa de determinar el ámbito territorial de la Ley.

Así, el artículo 2 dispone:

«Artículo 2. Ambito territorial. Disposiciones imperativas.

La presente Ley se aplicará a las cláusulas de condiciones generales que formen parte de contratos sujetos a la legislación espanola.

También se aplicará a los contratos sometidos a la legislación extranjera cuando el adherente haya emitido su declaración negocial en el territorio español y tenga en éste su domicilio o residencia habitual, sin perjuicio de lo establecido en Tratados o Convenios internacionales».

\subsection{Contratos excluidos}

El artículo 3 del Proyecto se refiere a los «contratos excluidos», respecto de los cuales dice la Exposición de Motivos: 
«Desde el punto de vista objetivo se excluyen ciertos contratos que por sus características específicas, por la materia que tratan y por la alienidad de la idea de predisposición contractual, no deben estar comprendidos en la Ley, como son los administrativos, los de trabajo, los societarios, los que regulen relaciones familiares y los sucesorios.»

Así, ese artículo 3 dice:

\section{«Artículo 3. Contratos excluidos}

La presente Ley no se aplicará a los contratos administrativos, a los contratos de trabajo, a los de sociedad, a los que regulan relaciones familiares y a los contratos sucesorios.

Tampoco será de aplicación esta Ley a las condiciones generales que reflejen las disposiciones o los principios de los Convenios internacionales en que el Reino de España sea parte, ni las que vengan reguladas específicamente por una disposición legal o administrativa de carácter general y que sean de aplicación obligatoria para los contratantes.»

En lo que respecta a la exclusión de todos los supuestos de condiciones generales regulados específicamente por una disposición legal o administrativa de carácter general y de aplicación obligatoria, la Memoria señala que el sentido fundamental de esta exclusión es respetar la legislación en la materia de sectores específicos, como el asegurador, que dispone ya de órganos propios de control. No obstante, téngase presente que la disposición adicional primera del proyecto introduce a su vez una disposición adicional segunda en la LCU, con el siguiente texto: "Disposición adicional segunda. Ambito de aplicación. Lo dispuesto en la presente Ley será de aplicación a todo tipo de contratos en los que intervengan consumidores, con las condiciones y requisitos en ella establecidos, a falta de normativa sectorial específica, que en cualquier caso respetará el nivel de protección del consumidor previsto en aquélla.»

\subsection{Requisitos de incorporación y cláusulas no incorporadas}

Los artículos 4 y 5 del Proyecto, siguiendo una terminología muy arraigada en esta materia, aunque a mi juicio no demasiado afortunada, determinan respectivamente los «requisitos de incorporación» y las «cláusulas no incorporadas».

El primero de esos preceptos trata, en definitiva, de determinar cuándo unas condiciones generales forman parte del contrato. Circunstancia que no pasaría de ser una mera curiosidad académica si no fuera porque son precisamente las condiciones generales «incorporadas» las 
que pueden ser objeto de sanción de nulidad; no sólo porque así se desprende del Capítulo II de la Ley, sino por obvia coherencia técnica.

1. Ese artículo 4 contempla los «requisitos de incorporación»a la luz de elementales principios científicos y con una razonable contemplación de algunas formas de contratación que el tráfico económico impone.

Reza así el precepto:

«Artículo 4. Requisitos de incorporación

1. Las condiciones generales pasan a formar parte del contrato cuando su incorporación al mismo haya sido aceptada por el adherente y hayan sido firmadas por los contratantes.

No podrá entenderse que ha habido aceptación de la incorporación de las condiciones generales al contrato cuando el predisponente no haya informado expresamente al adherente acerca de su existencia, y no le haya facilitado un ejemplar de las mismas.

2. Cuando el contrato no deba formalizarse por escrito y el predisponente entregue un resguardo justificativo de la contraprestación recibida, bastará con que el predisponente anuncie las condiciones generales en un lugar visible dentro del lugar en el que se celebra el negocio, que las inserte en la documentación del contrato que acompaña su celebración; o que, de cualquier otra forma, garantice al adherente una posibilidad efectiva de conocer su existencia y contenido en el momento de la celebración.

3. La redacción de las cláusulas generales deberá ajustarse a los criterios de transparencia, claridad, concreción y sencillez.

4. En los casos de contratación telefónica o electrónica, será necesario que conste la aceptación de todas y cada una de las cláusulas del contrato, sin necesidad de firma convencional.»

Quedan razonablemente descritos los requisitos para que unas condiciones generales se consideren efectivamente «incorporadas» al contrato, con atención, también justificada, a determinadas modalidades de contratación que era necesario contemplar.

Me produce perplejidad, no obstante, el apartado 3 del artículo, puesto que en rigor no se trata de «requisitos de incorporación», sino de requisitos de eficacia de las condiciones generales (en el sentido de que deben ajustarse a los criterios de transparencia, claridad, concreción y sencillez); esto a tenor del apartado 1 del artículo 7, al que luego me referiré, que formula una regla general descriptiva de la nulidad de pleno derecho de que pueden adolecer las condiciones generales. A no ser que se ponga el énfasis en las palabras «en perjuicio del adherente» 
que utiliza esta última norma, puesto que no cabe excluir que las cláusulas generales no se ajusten a los criterios antes mentados (los del apartado 3 del artículo que nos ocupa), y en cambio ese perjuicio a que se refiere el artículo 7 no se produzca.

En cualquier caso, parece que este apartado 3 es un «cuerpo extraño» en la lógica del artículo 4. Me parecería más adecuado que el contenido de ese apartado, expresado a sensu contrario, se hubiese incluido en el artículo 5, dentro de la no muy satisfactoria fórmula de la llamada «no incorporación».

Interesa señalar la justificación que la Memoria del Proyecto da a los «casos excepcionales» del apartado 2. Se dice al respecto:

«Sólo en los supuestos en los que por razón de las especiales circunstancias del contrato la obligación de informar y facilitar las condiciones generales sea desproporcionada (como es el caso de los contratos en los que no sea obligatorio formalizar el contrato por escrito), se considera suficiente para su eficacia que el adherente haya tenido la posibilidad real de conocerlas, sin necesidad de un conocimiento efectivo ni de firma. Es el caso de sectores como el transporte u otros dirigidos a una contratación masiva, en los que sería desorbitado exigir una información efectiva de las condiciones generales y su entrega al usuario.»

2. De conformidad con el criterio que rige el Proyecto en este punto, esto es, el de hablar de «cláusulas incorporadas» (aunque con otras palabras) y de «cláusulas no incorporadas», el artículo 5 de la Ley sería del siguiente tenor:

«Artículo 5. Cláusulas no incorporadas

No quedarán incorporadas al contrato las siguientes condiciones generales:

a) aquellas que no haya tenido oportunidad el adherente de tomar conocimiento real al tiempo de la celebración del contrato o cuando no hayan sido firmadas cuando sea necesario, en los términos resultantes del artículo anterior;

b) las que sean ilegibles, ambiguas, incomprensibles u oscuras, salvo, en cuanto a estas últimas, que hubieren sido expresamente aceptadas por escrito por el adherente y se ajusten a la normativa específica que discipline en su ámbito la necesaria transparencia de las cláusulas contenidas en el contrato;

c) las que de acuerdo con las circunstancias y, en especial, con la naturaleza del contrato, resulten tan insólitas que el adherente no hubiera podido contar razonablemente con su existencia.» 
Como decía antes, la propia terminología de «no incorporación» me parece poco adecuada.

En concreto, creo razonable que se consideren como tales las del apartado a) del precepto, porque, verdaderamente, las condiciones generales a que se refiere no han sido objeto de una declaración de voluntad por parte del adherente que merezca esa calificación. Diríase que lo que constituye el referido apartado es, en rigor, una tautología o redundancia, puesto que en estrictos términos técnicos - a la luz del texto legal que nos ocupa- no existe siquiera «cláusula».

Pero, por lo que respecta a los casos de los apartados b) y c), hablar de «no incorporación» es una auténtica ficción. Las cláusulas o condiciones generales a que dichos apartados se refieren sí están incorporadas al contrato, diga lo que diga el precepto. Cosa distinta es que no sean eficaces, en términos amplios, o que - acudiendo a los conceptos del propio Proyecto- sean nulas de acuerdo con su artículo 7.

\subsection{Reglas de interpretación}

El artículo 6 del Proyecto formula dos reglas hermenéuticas de incuestionable lógica y, en el fondo, no del todo nuevas en nuestro sistema jurídico, salvo en su formulación con el carácter general con que lo hace el texto que analizamos.

Dice esa norma:

«Artículo 6. Reglas de interpretación

1. Cuando exista contradicción entre las condiciones generales y las específicamente previstas para el contrato concreto, prevalecerán éstas sobre aquéllas, salvo que las condiciones generales resulten más beneficiosas para el adherente que las condiciones particulares.

2. Las dudas en la interpretación de las condiciones generales oscuras se resolverán a favor del adherente.»

En el apartado 1 se hace prevalecer el beneficio del adherente contra lo que sería una solución técnica fundada si no se hablase de condiciones generales; me refiero a la prevalencia o primacía de lo particular o especial sobre lo general.

En cuanto al apartado 2, es claro que la norma va más lejos de lo que exige el tradicional criterio hermenéutico que damos en llamar «interpretatio contra proferentem», con asiento en el artículo 1.288 del Código civil, puesto que el precepto no se limita a decir que las oscuridades no deben favorecer a la parte que las hubiere ocasionado, sino que, yendo también más allá, establece que se resolverán a favor del adherente. 
3.7. Nulidad de las condiciones generales. La propia de las abusivas

1. El Capítulo II de la Ley proyectada comprende tres artículos, el 7, 8 y 9, bajo la rúbrica general de «nulidad y no incorporación de determinadas condiciones generales».

El primero de esos artículos dice:

«Artículo 7. Norma general. Nulidad de las condiciones generales

1. Serán nulas de pleno derecho las condiciones generales que contradigan en perjuicio del adherente lo dispuesto en esta Ley o en cualquier otra norma imperativa o prohibitiva, salvo que en ellas se establezca un efecto distinto para el caso de contravención.

2. En particular, serán nulas las condiciones generales que sean abusivas, cuando el contrato se haya celebrado con un consumidor, entendiendo por tales en todo caso las definidas en el artículo 10 bis y disposición adicional primera de la Ley General para la Defensa de Consumidores y Usuarios.»

El apartado 1 adopta el criterio de sanción general de nulidad del artículo 6.3 del Código civil, que sin embargo debe ser matizado con la fórmula de nulidad parcial o conservación del negocio jurídico que se establece en el artículo 9, como en seguida veremos.

No podía ser de otro modo, si tenemos en cuenta que esa nulidad se predica respecto de las condiciones generales en tanto en cuanto contradigan lo dispuesto en normas imperativas o prohibitivas; pero siendo «en perjuicio del adherente», como puntualiza el precepto.

El apartado 2 enlaza con la doctrina de las cláusulas abusivas (que - no se olvide - es el objeto de la Directiva cuya transposición al Derecho español constituye uno de los propósitos del Proyecto), al declarar nulas las condiciones generales que sean abusivas (si bien cuando el contrato sea celebrado con un consumidor). Lo que implica la toma en consideración del concepto de cláusula abusiva establecido en el nuevo artículo 10 bis que el Proyecto introduce en la LCU, así como el elenco o lista de cláusulas abusivas que el propio Proyecto incluye así mismo en la LCU, como disposición adicional primera.

El artículo 8, bajo la equívoca rúbrica de «régimen de la nulidad», lo que hace en rigor es formular ciertas reglas procesales sobre la declaración de nulidad, pero también sobre la denominada «declaración de no incorporación».

Es claro que la primera de esas declaraciones tiene su asiento sustantivo en el artículo 7 que acabamos de examinar, mientras que la segunda lo encuentra en el artículo 5 antes analizado. 
2. Ese artículo 8 dispone:

\section{"Artículo 8. Régimen de la nulidad}

1. La declaración judicial de no incorporación al contrato o de nulidad de las cláusulas de condiciones generales, podrá ser instada por el adherente de acuerdo con las reglas generales reguladoras de la nulidad contractual y tendrá los efectos previstos en el artículo siguiente.

2. La sentencia estimatoria obtenida en un proceso incoado mediante el ejercicio de la acción individual de nulidad o de declaración de no incorporación, decretará la nulidad o no incorporación al contrato de las cláusulas generales afectadas.»

3. Sin perjuicio de lo anterior, el mayor interés radica en el contenido del artículo 9, que dice:

«Artículo 9. Efectos de la no incorporación y de la nulidad

1. La no incorporación al contrato de las cláusulas de las condiciones generales o la declaración de nulidad de las mismas, no determinará la ineficacia total del contrato, si éste puede subsistir sin tales cláusulas.

2. La parte del contrato afectada por la no incorporación o por la nulidad se integrará con arreglo a lo dispuesto por el artículo 1.258 del Código civil.»

Como decía antes, se observará que este último precepto se ajusta al principio de «conservación del negocio jurídico» o, dicho de otro modo, a la «nulidad parcial», si, declarada la nulidad o la no incorporación al contrato de algunas cláusulas de las condiciones generales, el contrato puede - no obstante- subsistir sin ellas. Parece claro que esto último ocurrirá cuando las cláusulas en cuestión no afecten a los llamados «elementos esenciales» del contrato o a los «naturales» de la figura contractual de que en cada caso se trate.

Por otro lado, merece particular mención el apartado 2, por cuanto es realmente original (aunque no incorrecto) que una Ley especial aluda a la facultad de «integración del contrato» que con carácter general formula el artículo 1.258 del Código civil. Quizá esté la novedad en el hecho de que en esta norma no se reconoce esa simple facultad, sino que «se impone» al juez la operación integradora de que hablamos.

Hay que hacer notar que esta fórmula de integración del contrato por parte del juez se establece también (por natural coherencia) en el nuevo artículo 10 bis que el Proyecto pretende introducir en la LCU. Lo veremos más adelante al examinar el contenido de la disposición adicional primera de este Proyecto que nos ocupa. 


\section{El Registro de Condiciones Generales de la Contratación}

El Capítulo III del Proyecto (artículo 10) reglamenta un nuevo Registro de Condiciones Generales de la Contratación. El precepto dice:

"Artículo 10. Registro de Condiciones Generales

1. Se crea el Registro de Condiciones Generales de la Contratación, que estará a cargo de un Registrador de la Propiedad y Mercantil, conforme a las normas de provisión previstas en la Ley Hipotecaria.

La organización del citado Registro se ajustará a las normas que dicte el Ministerio de Justicia.

2. En dicho Registro podrán inscribirse las cláusulas contractuales que tengan el carácter de condiciones generales de la contratación con arreglo a lo dispuesto en la presente Ley, a cuyo efecto se presentarán para su depósito, por duplicado, los ejemplares, tipo o modelos en que se contengan, a instancia de cualquier interesado. No obstante, el Gobierno, a propuesta conjunta del Ministerio de Justicia y del departamento ministerial correspondiente, podrá imponer la inscripción obligatoria en el Registro de las Condiciones Generales en determinados sectores específicos de la contratación.

3. Serán objeto de anotación preventiva la interposición de las demandas ordinarias de nulidad o de declaración de no incorporación de cláusulas generales, así como las acciones colectivas de cesación, de retractación y declarativa previstas en el capítulo IV.

Dichas anotaciones preventivas tendrán una vigencia de cuatro años a contar desde su fecha, siendo prorrogables hasta la terminación del procedimiento en virtud de mandamiento judicial de prórroga.

4. Serán objeto de inscripción las ejecutorias en que se recojan sentencias firmes estimatorias de cualquiera de las acciones a que se refiere el apartado anterior. También podrá ser objeto de inscripción, cuando se acredite suficientemente al Registrador, la persistencia en la utilización de cláusulas declaradas judicialmente nulas.

5. El Registro de Condiciones Generales de la Contratación será público.

6. El Registrador calificará el interés del solicitante de información relativa a los asientos registrales, presumiendo tal interés en las Entidades a que se refiere el artículo 12.

7. La publicidad de los asientos registrales se realizará bajo la responsabilidad y control profesional del Registrador.

8. La inscripción de las condiciones generales podrá solicitarse por los contratantes, los legitimados para ejercitar la acción colectiva 
y, en caso de anotación de demanda o sentencia judicial, en virtud del mismo mandamiento, que las incorporará.

9. Contra la calificación por el Registrador del interés del solicitante de la inscripción de las condiciones generales o de información relativa a los asientos registrales, podrá recurrirse ante el Presidente del Tribunal Superior de Justicia correspondiente, si residiese en el mismo lugar que aquél o, en otro caso, al Juez de Primera Instancia, quienes decidirán oyendo al Registrador. Contra la decisión de los mismos podrá recurrirse ante la Dirección General de los Registros y del Notariado.»

Son muchos los interrogantes que plantea este Registro que el Proyecto prevé. El primero y principal, a mi juicio, radica en si está o no justificado que se constituya todo un «aparato registral» para la modestia de los objetivos que con ese Registro se persiguen.

\section{Acciones colectivas de cesación, retractación y declarativa de condiciones generales}

El Capítulo IV del Proyecto dedica nueve artículos (11 a 19) a las acciones denominadas en la forma que se dice en el epígrafe, rúbrica a su vez de dicho capítulo.

Interesan sobre todo los artículos 11 y 19, que revelan suficientemente el carácter y los objetivos de esas acciones de nuevo cuño.

El artículo 11 reza:

«Artículo 11. Acciones de cesación, retractación y declarativa

1. Contra la utilización o la recomendación de utilización de condiciones generales que resulten contrarias a lo dispuesto en esta Ley, o en otras leyes imperativas o prohibitivas, podrán interponerse, respectivamente, acciones de cesación y retractación.

2. La acción de cesación se dirige a obtener una sentencia por medio de la cual se condene al demandado a eliminar de sus condiciones generales las que se reputen nulas y a abstenerse de utilizarlas en lo sucesivo.

3. Por medio de la acción de retractación se insta la imposición al demandado, sea o no el predisponente, de la obligación de retractarse de la recomendación que haya efectuado de utilizar las cláusulas de condiciones generales que se consideren nulas y de abstenerse de seguir recomendándolas en el futuro, siempre que hayan sido efectivamente utilizadas por el predisponente en alguna ocasión.

4. La acción declarativa tendrá por objeto el reconocimiento de una cláusula como condición general de contratación, e instar su ins- 
cripción únicamente cuando ésta sea obligatoria conforme al artículo 10.2 inciso final de la presente Ley.»

Y, en coherencia con ese artículo 11 (no exenta de alguna redundancia), el artículo 19 dispone:

«Artículo 19. Efectos de la sentencia

1. La sentencia estimatoria obtenida en un proceso incoado mediante el ejercicio de la acción de cesación, impondrá al demandado la obligación de eliminar de sus condiciones generales las cláusulas que declare contrarias a lo prevenido en esta Ley o en otras leyes imperativas y la de abstenerse de utilizarlas en lo sucesivo.

2. Si la acción ejercitada fuera la de retractación, la sentencia impondrá al demandado la obligación de retractarse de la recomendación efectuada, y de abstenerse de su recomendación futura, de aquellas cláusulas de condiciones generales que hayan sido consideradas contrarias a Derecho.

3. Si la acción ejercitada fuera la declarativa, la sentencia declarará el carácter de condición general de la cláusula o cláusulas afectadas y dispondrá su inscripción en el Registro de Condiciones Generales.

4. La sentencia que estime la acción de cesación, una vez adquiera firmeza, vinculará a todos los jueces en los eventuales ulteriores procesos en que se inste la nulidad de cláusulas idénticas a las que hubieran sido objeto de la referida sentencia, siempre que se trate del mismo predisponente.»

Los artículos 12 a 18 disponen reglas de carácter procesal para el ejercicio de estas acciones.

El artículo 15 establece la legitimación activa para el ejercicio de estas acciones colectivas.

Dice al respecto:

«Artículo 15. Legitimación activa

Las acciones previstas en el artículo anterior podrán ser ejercitadas por las siguientes entidades:

1. Las Asociaciones o Corporaciones de empresarios, profesionales y agricultores que estatutariamente tengan encomendada la defensa de los intereses de sus miembros.

2. Las Cámaras de Comercio, Industria y Navegación.

3. Las Asociaciones de Consumidores y Usuarios legalmente constituidas.

4. El Instituto Nacional de Consumo y los órganos correspondientes de las Comunidades Autónomas y de las Corporaciones Locales competentes en materia de defensa de los consumidores.» 
El artículo 18 se refiere a la prescripción de las acciones colectivas que nos vienen ocupando. Dice el precepto:

«Artículo 18. Prescripción

Las acciones colectivas de cesación y retractación prescriben por el transcurso de dos años desde el momento en que se practicó la inscripción de las condiciones generales cuya utilización o recomendación pretenden hacer cesar.

Tales acciones, no obstante, podrán ser ejercitadas en todo caso durante el año siguiente a la declaración judicial firme de nulidad o no incorporación que pueda dictarse con posterioridad como consecuencia de una acción individual.

La acción declarativa es imprescriptible.»

\section{La disposición adicional primera de la Ley}

Con esta disposición adicional se introducen notables modificaciones de la LCU. Voy a ocuparme de las más significativas.

\subsection{La nueva redacción del artículo 10 de la $L C U$}

Según el número dos de esta disposición adicional primera, el artículo 10 de la LCU adquiere una nueva redacción, ajustada al nuevo régimen de las condiciones generales contenido en el articulado (en sentido estricto) de la Ley proyectada.

Así, el precepto mentado queda redactado de la siguiente forma:

"Artículo 10.1. Las cláusulas, condiciones o estipulaciones que se apliquen a la oferta o promoción de productos o servicios, y las cláusulas no negociadas individualmente relativas a tales productos o servicios, incluidos los que faciliten las Administraciones Públicas y las Entidades y Empresas de ellas dependientes, deberán cumplir los siguientes requisitos:

a) Concreción, claridad y sencillez en la redacción, con posibilidad de comprensión directa, sin reenvíos a textos o documentos que no se faciliten previa o simultáneamente a la conclusión del contrato, y a los que, en todo caso, deberá hacerse referencia expresa en el documento contractual.

b) Entrega, salvo renuncia expresa del interesado, de recibo justificante, copia o documento acreditativo de la operación, o en su caso, de presupuesto debidamente explicado. 
c) Justo equilibrio entre los derechos y obligaciones de las partes, lo que en todo caso excluye la utilización de cláusulas abusivas en los términos y con el alcance que prescribe el siguiente artículo 10 bis.

2. En el caso de duda sobre el sentido de una cláusula prevalecerá la interpretación más favorable para el consumidor.

3. Si las cláusulas tienen el carácter de condiciones generales, conforme a la Ley sobre Condiciones Generales de la Contratación, quedarán también sometidas a las prescripciones de ésta, en aquello que no esté regulado en la presente Ley.

4. Los convenios arbitrales establecidos en la contratación a que se refiere este artículo serán eficaces si, además de reunir los requisitos que para su validez exigen las leyes, resultan claros y explícitos. La negativa del consumidor o usuario a someterse a un sistema arbitral distinto del previsto en el artículo 31 de esta Ley no podrá impedir por sí misma la celebración del contrato principal.

5. Las cláusulas, condiciones o estipulaciones que utilicen las empresas públicas o concesionarias de servicios públicos estarán sometidas a la aprobación y control de las Administraciones Públicas competentes, cuando así se disponga como requisito de validez y con independencia de la consulta prevista en el artículo 22 de esta Ley. Todo ello sin perjuicio de su sometimiento a las disposiciones generales de esta Ley.

6. Los Notarios advertirán a los consumidores del posible carácter abusivo de las cláusulas contenidas en los contratos o negocios jurídicos que autoricen, así como de su posible ineficacia o nulidad, sin perjuicio de lo dispuesto en la normativa notarial.

Los Registradores de la Propiedad y Mercantiles calificarán, bajo su responsabilidad, el carácter abusivo de las cláusulas que afecten a la eficacia real de los derechos inscribibles, denegando su inscripción sin perjuicio de los recursos judicial o gubernativo, regulados por la legislación hipotecaria, que pudieran interponerse.

Los Notarios, los Corredores de Comercio y los Registradores de la Propiedad y Mercantiles, en el ejercicio profesional de sus respectivas funciones públicas, informarán a los consumidores en los asuntos propios de su especialidad y competencia.»

6.2. Introducción de un nuevo artículo 10 bis y de una disposición adicional primera en la LCU (régimen específico de las cláusulas abusivas)

1. El número tres de la disposición adicional en que nos encontramos añade o introduce un nuevo artículo 10 bis en la LCU, con la fina- 
lidad fundamental de establecer en él el concepto y las consecuencias de las «cláusulas abusivas».

Ese artículo 10 bis es del siguiente tenor:

«Artículo 10 bis. 1. Se considerarán cláusulas abusivas todas aquellas estipulaciones no negociadas individualmente que en contra de las exigencias de la buena fe causen, en perjuicio del consumidor, un desequilibrio importante de los derechos y obligaciones de las partes que se derivan del contrato. En todo caso se considerarán cláusulas abusivas los supuestos de estipulaciones que se relacionan en la disposición adicional de la presente Ley.

El hecho de que ciertos elementos de una cláusula o que una cláusula aislada se hayan negociado individualmente no excluirá la aplicación de este artículo al resto del contrato.

El profesional que afirme que una determinada cláusula ha sido negociada individualmente, asumirá la carga de la prueba.

El carácter abusivo de una cláusula se apreciará teniendo en cuenta la naturaleza de los bienes o servicios objeto del contrato y considerando todas las circunstancias concurrentes en el momento de su celebración, así como todas las demás cláusulas del contrato o de otro del que éste dependa.

Tal apreciación no se referirá a la definición del objeto principal del contrato ni a su adecuación con el precio pactado, siempre que las cláusulas que lo definan se redacten de manera clara y comprensible.

2. Serán nulas de pleno derecho y se tendrán por no puestas las cláusulas, condiciones y estipulaciones en las que se aprecie el carácter abusivo. La parte del contrato afectada por la nulidad se integrará con arreglo a lo dispuesto por el artículo 1.258 del Código civil. A estos efectos, el Juez que declare la nulidad de dichas cláusulas integrará el contrato y dispondrá de facultades moderadoras respecto de los derechos y obligaciones de las partes, cuando subsista el contrato, $y$ de las consecuencias de su ineficacia en caso de perjuicio apreciable para el consumidor o usuario. Sólo cuando las cláusulas subsistentes determinen una situación no equitativa en la posición de las partes que no pueda ser subsanada podrá declarar la ineficacia del contrato.

3. Cualquiera que sea la Ley que las partes hayan elegido para regir el contrato, las normas de protección de los consumidores frente a las cláusulas abusivas serán aplicables siempre que el contrato mantenga estrecha relación con el territorio de un Estado miembro de la Unión Europea.»

Lo más importante es la definición de cláusula abusiva, que se contiene en el apartado 1 de este artículo de nueva planta. Son dos los ele- 
mentos que en suma determinan esa noción: de un lado, la actuación en contra de las exigencias de la buena fe (requisito subjetivo), y de otro la circunstancia objetiva de que las cláusulas causen un desequilibrio importante de los derechos y obligaciones de las partes que derivan del contrato.

Pero, con independencia de esa descripción general, interesa advertir que el último inciso del párrafo primero de ese apartado 1 dispone que «en todo caso» son abusivas las cláusulas que se relacionan en la disposición adicional de la LCU (otra novedad que en cuanto a esta última Ley introduce el Proyecto que nos ocupa). En seguida volvemos sobre esto.

Por lo que se refiere a la noción de cláusula abusiva, creo que interesa reproducir lo que al respecto dice la Memoria del Proyecto:

«Son requisitos para que concurra la cualidad de cláusula abusiva:

a) Que se trate de un contrato celebrado con un consumidor.

b) Que se trate de estipulaciones no negociadas individualmente.

c) Que sean contrarias a la buena $\mathrm{fe}^{18}$. A pesar de lo que ha entendido algún sector de la doctrina, no son las condiciones generales de los contratos las que deben vincularse a la buena fe, como tales, sino las cláusulas contractuales en general, en particular dentro de los contratos de adhesión, sean particulares o condiciones dirigidas a una pluralidad de contratos.

d) Que produzcan un desequilibrio importante de los derechos y obligaciones derivados del contrato.

e) Es un concepto no estático. El carácter abusivo de una cláusula se aprecia teniendo en cuenta la naturaleza de los bienes o servicios objeto del contrato y considerando todas las circunstancias concurrentes en el momento de su celebración, así como todas las demás cláusulas del contrato o de otro del que éste dependa.

f) Nunca el carácter abusivo puede derivar de la materia objeto del contrato ni de su adecuación con el precio pactado, siempre que las cláusulas que lo definan se redacten de manera clara y comprensible».

2. Según hemos venido diciendo, y como por otra parte anuncia el último inciso del párrafo primero del apartado 1 del nuevo artículo 10 bis de la LCU, el Proyecto introduce en esta última una nueva disposi-

18 La propia Memoria advierte en nota de la página 23 que se ha modificado la expresión «pese a las exigencias de la buena fe» por el de «contrarias a la buena fe», ya que aunque la primera expresión es más ajustada a la Directiva, la segunda expresa más correctamente la necesidad de que para que exista abuso contractual debe existir mala fe, entendida en su aspecto subjetivo; el aspecto objetivo de desequilibrio contractual también es exigido, pero separadamente de la mala fe. 
ción adicional (que queda como primera). Es fruto del número seis de, a su vez, la disposición adicional primera de la Ley proyectada.

El Proyecto, por tanto, adopta al respecto la fórmula de la propia Directiva, en el sentido de establecer un elenco o lista de cláusulas abusivas. La Exposición de motivos del Proyecto dice que es una «enumeración enunciativa» de cláusulas abusivas, extraídas en sus líneas generales de la Directiva pero añadiendo también aquellas otras que, aun sin estar previstas en ella, se estima necesario que estén incluidas en el Derecho español por su carácter claramente abusivo. En otro lugar de la Exposición de Motivos se manifiesta que, de esta forma, se ejercita la facultad del Estado obligado a transponer la Directiva de poder incrementar el nivel de protección más allá de las obligaciones mínimas que aquélla impone.

No es el caso de transcribir esa larga lista de cláusulas que se consideran abusivas, por lo que me remito al texto del Proyecto para su detalle. Son 29 casos, divididos en cinco grupos: I. Las que suponen una vinculación del contrato a la voluntad del profesional $\left(1 .^{\mathrm{a}}\right.$ a $\left.8 .^{\mathrm{a}}\right)$; II. Las que suponen la privación de derechos básicos del consumidor $\left(9 .^{\mathrm{a}} \mathrm{a}\right.$ 14. ${ }^{\mathrm{a}}$ ); III. Las que son abusivas por falta de reciprocidad $\left(15 .^{\mathrm{a}}\right.$ a $\left.17 .{ }^{\mathrm{a}}\right)$; IV. Sobregarantías $\left(18 .^{\mathrm{a}}\right.$ y $\left.19 .^{\mathrm{a}}\right)$; V. Otras cláusulas abusivas $\left(20 .^{\mathrm{a}} \mathrm{a}\right.$ 29. ${ }^{a}$.

3. Procede señalar que, según el último párrafo de la nueva disposición adicional primera de la LCU que se proyecta, "se entenderá por profesional, a los efectos de esta disposición adicional, la persona física o jurídica que actúa dentro de su actividad profesional, ya sea pública o privada». 